Article

\title{
Pyridine and $p$-Nitrophenyl Oxime Esters with Possible Photochemotherapeutic Activity: Synthesis, DNA Photocleavage and DNA Binding Studies
}

\author{
Milena Pasolli 1, + , Konstantinos Dafnopoulos 1,2,+, Nicolaos-Panagiotis Andreou ${ }^{1}$, \\ Panagiotis S. Gritzapis ${ }^{1}$, Maria Koffa ${ }^{3}$, Alexandros E. Koumbis ${ }^{4}$, George Psomas ${ }^{2}$ and \\ Konstantina C. Fylaktakidou ${ }^{1, *}$ \\ 1 Laboratory of Organic, Bioorganic and Natural Product Chemistry, Molecular Biology and \\ Genetics Department, Democritus University of Thrace, University Campus, Dragana, \\ GR-68100 Alexandroupolis, Greece; milepasolli@gmail.com (M.P.); konsdafn1@mbg.duth.gr (K.D.); \\ nickpanandreou@hotmail.com (N.-P.A.); psgritzapis@gmail.com (P.S.G.) \\ 2 Laboratory of Inorganic Chemistry, Chemistry Department, Aristotle University of Thessaloniki, \\ GR-54124 Thessaloniki, Greece; gepsomas@chem.auth.gr \\ 3 Laboratory of Cellular Biology and Cell Cycle, Molecular Biology and Genetics Department, \\ Democritus University of Thrace, University Campus, Dragana, GR-68100 Alexandroupolis, Greece; \\ mkoffa@mbg.duth.gr \\ 4 Laboratory of Organic Chemistry, Chemistry Department, Aristotle University of Thessaloniki, \\ GR-54124 Thessaloniki, Greece; akoumbis@chem.auth.gr \\ * Correspondence: kfylakta@mbg.duth.gr; Tel.: +30-25510-30663 \\ + These authors contributed equally to this work.
}

Academic Editor: Jean Jacques Vanden Eynde

Received: 30 May 2016; Accepted: 28 June 2016; Published: 30 June 2016

\begin{abstract}
Compared to standard treatments for various diseases, photochemotherapy and photo-dynamic therapy are less invasive approaches, in which DNA photocleavers represent promising tools for novel "on demand" chemotherapeutics. A series of $p$-nitrobenzoyl and $p$-pyridoyl ester conjugated aldoximes, amidoximes and ethanone oximes were subjected to UV irradiation at $312 \mathrm{~nm}$ with supercoiled circular plasmid DNA. The compounds which possessed appropriate properties were additionally subjected to UVA irradiation at $365 \mathrm{~nm}$. The ability of most of the compounds to photocleave DNA was high at $312 \mathrm{~nm}$, whereas higher concentrations were required at $365 \mathrm{~nm}$ as a result of their lower UV absorption. The affinity of selected compounds to calf-thymus (CT) DNA was studied by UV spectroscopy, viscosity experiments and competitive studies with ethidium bromide (EB) revealing that all compounds interacted with CT DNA. The fluorescence emission spectra of the pre-treated EB-DNA exhibited a moderate to significant quenching in the presence of the compounds indicating the binding of the compounds to CT DNA via intercalation as concluded also by DNA-viscosity experiments. For the oxime esters the DNA photocleavage and affinity studies aimed to clarify the role of the oxime nature (aldoxime, ketoxime, amidoxime) and the role of the pyridine and $p$-nitrophenyl moieties both as oxime substituents and ester conjugates.
\end{abstract}

Keywords: photo-cleavage; DNA photo-cleavers; DNA binding; oxime esters; amidoxime; aldoxime; ketoxime

\section{Introduction}

Photochemotherapy and photodynamic therapy are, compared to standard treatments for various types of cancer, less invasive approaches [1-5]. The advantage of light, when used as a co-factor of a therapeutic process, is that it provides localized photo-activation of the drug at the targeted tumor cells. In pharmacology, the interaction of drugs with DNA is an important feature which plays a 
significant role in the determination of the drug action mechanism as well as in the designing of more efficient, specifically targeting drugs with less side effects. Thus, DNA is among the cellular targets for photo-activated drugs, as well as for many cytotoxic anticancer agents [6,7]. Photo-activated "chemical nucleases", known also as "photocleavers" [8-14], interact with DNA and cause its cleavage when exited with light of a proper wavelength. The need for external chemical initiators is eliminated, due to the fact that the chemical reaction occurs only when the mixture of the photo-cleaver and DNA is irradiated. The excited photocleaver initiates reactions which via various mechanistic pathways [2,4,14] may lead to single-strand (ss) DNA damage, repairable by enzymatic processes [15], and/or double-strand (ds) DNA cleavage $[13,16,17]$. The latter, which is more difficult to repair, may trigger self-programmed cell death, making this approach an efficient tool for cancer therapy.

Aldoximes, ketoximes and amidoximes (Figure 1, general structures I, II and III, respectively) retain a complementary position in drug design and discovery since they are individually considered as pharmacophores. They, additionally, participate as parent compounds in multiple transformations leading to biologically interesting derivatives [18-23]. Oxime carboxylates (Figure 1, general structures $\mathbf{I b}, \mathbf{I I b}$ and IIIb) have the ability to act as metal free DNA photocleavers, with aroyl conjugates shown to be the most active ones [24-30]. In this case, homolysis of the weak N-O bond of the oximes generates active aroyloxyl radicals (ArCOO ${ }^{*}$ ) able to attack DNA. On the other hand, aliphatic acyloxyl radicals may rapidly decarboxylate, producing thus less active radicals [31-33]. Very recently, alkyl and aryl ketoxime and amidoxime sulfonates (Figure 1, general structures IIc and IIIc, respectively) were found to be very efficient DNA photocleavers [34,35]. The ability of oximes to cleave phosphate bonds in nucleic acids and act as metal-free artificial nucleases has also been examined [36].

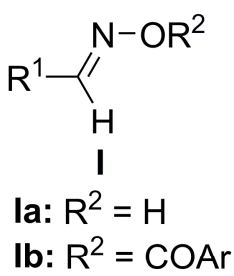

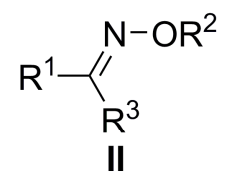

Ila: $\mathrm{R}^{2}=\mathrm{H}$

Ilb: $\mathrm{R}^{2}=\mathrm{COAr}$

Ilc: $\mathrm{R}^{2}=\mathrm{SO}_{2} \mathrm{Ar}$

or $\mathrm{SO}_{2} \mathrm{Alk}$<smiles></smiles>

Illa: $\mathrm{R}^{2}=\mathrm{H}$

IIlb: $\mathrm{R}^{2}=\mathrm{COAr}$

Illc: $\mathrm{R}^{2}=\mathrm{SO}_{2} \mathrm{Ar}$

or $\mathrm{SO}_{2} \mathrm{Alk}$

Figure 1. General structures of aldoximes (I), ketoximes (II); amidoximes (III); and their derivatives (Ib, IIb, IIIb, IIc, IIIc), which exhibit photo-cleaving activity.

Pyridine oxime derivatives exhibit a diverse biological profile, including cytotoxic, antiviral, analgesic, cardiovascular, anti-inflammatory, antidiabetic and antispasmodic activities [37]. Additionally, they are widely known as efficient reactivators of nerve agent inhibited acetylcholinesterases, offering a treatment from poisoning by organophosphorous compounds [38-40]. Our team has a continuous interest in the chemistry and biology of oximes [23,41-50] as well as in the DNA photocleavage caused by oxime derivatives $[30,34,35]$. We have discovered that $p$-nitro-benzoyl ester conjugates of pyridine aldoxime and amidoxime [30], as well as p-nitrophenyl sulfonates of pyridine ethanone oxime [34] and amidoxime [35] exemplified, among other conjugates, the best activities. The facts that (a) p-nitrophenyl carbamidoxime sulfonates are active derivatives with good affinity to calf-thymus (CT) DNA [35]; (b) p-nitrobenzoyl groups may exhibit their own photochemistry which could also lead to DNA cleavage [51-54]; (c) pyridoyl moieties show activity as heterocyclic oxime ester conjugates [28]; and (d) the pyridine moieties in vitamin B6 are endogenous photosensitizers [55] have prompted us to further investigate the role of pyridine and $p$-nitrophenyl moieties as oxime substituents and ester conjugates (Figure 2, Results and Discussion) both with regards to the photocleaving ability of the compounds, as well as their affinity to DNA. 


\section{Results and Discussion}

\subsection{Chemistry}

All derivatives (Figure 2) have been synthesized by the reaction of the proper parent compound (amidoxime, ethanone oxime or aldoxime) with the corresponding acid chloride, in $\mathrm{CHCl}_{3}$ or $\mathrm{THF}$ as a solvent, under an argon atmosphere.<smiles>[Y][Z]1:[Y]c(C(N)=NOC(=O)c2ccc([N+](=O)[O-])cc2)cc1</smiles>

1: $X=\mathrm{N}, \mathrm{Y}=\mathrm{CH}, \mathrm{Z}=\mathrm{CH}$

2: $X=\mathrm{CH}, Y=N, Z=C H$

3: $X=\mathrm{CH}, Y=\mathrm{CH}, Z=\mathrm{N}$

4: $\mathrm{X}=\mathrm{CH}, \mathrm{Y}=\mathrm{CH}, \mathrm{Z}=\mathrm{C}-\mathrm{OMe}$

5: $\mathrm{X}=\mathrm{CH}, \mathrm{Y}=\mathrm{CH}, \mathrm{Z}=\mathrm{C}-\mathrm{NO}_{2}$

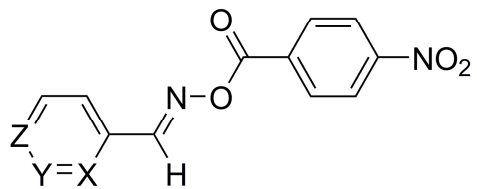

13: $X=\mathrm{N}, Y=\mathrm{CH}, Z=\mathrm{CH}$

14: $X=\mathrm{CH}, Y=\mathrm{N}, Z=\mathrm{CH}$

15: $X=\mathrm{CH}, Y=\mathrm{CH}, Z=\mathrm{N}$

16: $X=\mathrm{CH}, Y=\mathrm{CH}, \mathrm{Z}=\mathrm{C}-\mathrm{OMe}$<smiles>[Y][Z]1:[Y]c(/C(N)=N/OC(=O)c2ccncc2)cc1</smiles>

6: $X=\mathrm{N}, Y=\mathrm{CH}, Z=\mathrm{CH}$

7: $X=\mathrm{CH}, Y=\mathrm{N}, Z=\mathrm{CH}$

8: $X=\mathrm{CH}, Y=\mathrm{CH}, Z=\mathrm{N}$

9: $X=\mathrm{CH}, Y=\mathrm{CH}, \mathrm{Z}=\mathrm{C}-\mathrm{OMe}$

10: $\mathrm{X}=\mathrm{CH}, \mathrm{Y}=\mathrm{CH}, \mathrm{Z}=\mathrm{C}-\mathrm{NO}_{2}$<smiles>[Y][Z]1:[Y]c(/C=N/OC(=O)c2ccncc2)cc1</smiles>

17: $X=\mathrm{N}, Y=\mathrm{CH}, Z=\mathrm{CH}$

18: $X=\mathrm{CH}, Y=\mathrm{N}, Z=\mathrm{CH}$

19: $X=\mathrm{CH}, Y=\mathrm{CH}, Z=\mathrm{N}$

20: $\mathrm{X}=\mathrm{CH}, \mathrm{Y}=\mathrm{CH}, \mathrm{Z}=\mathrm{C}-\mathrm{OMe}$

21: $X=\mathrm{CH}, Y=\mathrm{CH}, \mathrm{Z}=\mathrm{C}-\mathrm{NO}_{2}$

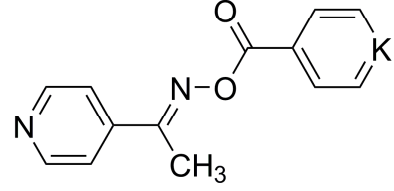

11: $\mathrm{K}=\mathrm{C}-\mathrm{NO}_{2}$

12: $\mathrm{K}=\mathrm{N}$

Figure 2. Structures of the amidoxime $p$-nitrobenzoyl conjugates (1-5), amidoxime pyridoyl conjugates (6-10), ethanone oxime $p$-nitrobenzoyl conjugate (11) and pyridoyl conjugates (12), aldoxime $p$-nitrobenzoyl conjugates (13-16) and aldoxime pyridoyl conjugates (17-21).

All reactions performed with the various oximes furnished the products in good yields, without the need, in most cases, of a chromatographic purification. The structure of the new compounds was fully assigned from their spectral data. Additionally, all compounds were found to absorb UV light at least partially over $300 \mathrm{~nm}$, as it was deduced from their UV-Vis spectra (see Supplementary Materials (SM), Figures S1-S3), with some exhibiting absorption at $365 \mathrm{~nm}$, allowing thus their irradiation at this wavelength as well. The stereochemistry of the synthesized aldoxime derivatives (regarding $\mathrm{H}$ ) was found to be syn [30]. Furthermore, all amidoxime derivatives have the Z-conformation, in accordance to what had previously been reported [22].

\subsection{DNA Photo-Cleavage Experiments}

DMF solutions of oxime conjugates 1-21 $(100 \mu \mathrm{M}$ or $500 \mu \mathrm{M})$ in DMF were mixed with a Tris buffer solution $(25 \mu \mathrm{M}, \mathrm{pH}=6.8)$ containing the supercoiled circular pBluescript KS II DNA or pBR322 (Form I) and this mixture was irradiated with UV light (312 nm for $15 \mathrm{~min}$ and/or $365 \mathrm{~nm}$ for $120 \mathrm{~min}$ ) at room temperature, under aerobic conditions. Plasmid DNA was analyzed by gel electrophoresis on $1 \%$ agarose stained with EB. All experiments were performed at least three times. None of the tested compounds showed any activity towards DNA in the absence of UV irradiation. The results obtained are shown in Figures 3 and 4 and in Table 1. 


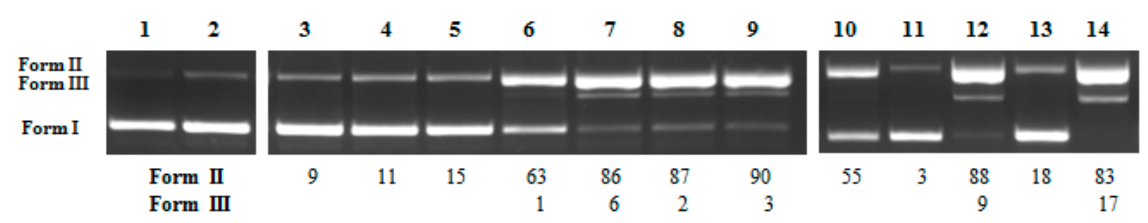

Figure 3. DNA photo-cleavage by various oxime ester conjugates at concentration of $100 \mu \mathrm{M}$ with plasmid DNA pBluescript KS II, at $312 \mathrm{~nm}$ for $30 \mathrm{~min}$. Top: Gel electrophoresis picture: Lane 1: DNA without UV irradiation; Lane 2: DNA with UV irradiation; Lanes 3-9: DNA + amidoximes or ethanone oxime derivatives $(\mathbf{6}, \mathbf{7}, \mathbf{8}, \mathbf{1 0}, \mathbf{1 2}, \mathbf{5}$, and 11, respectively) + UV irradiation; Lanes 10-14: DNA + aldoxime derivatives $(\mathbf{1 7}, \mathbf{1 8}, \mathbf{1 9}, \mathbf{2 0}$, and 21, respectively) + UV irradiation; Bottom: Calculation of the \% conversion to ss (Form II) and ds (Form III) damage.

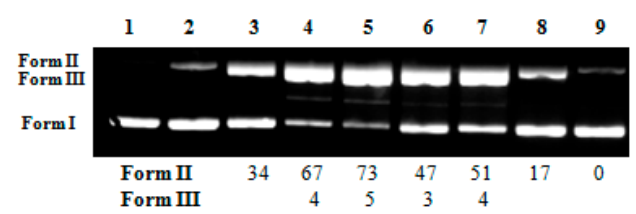

Figure 4. DNA photo-cleavage by various oxime ester conjugates at concentration of $500 \mu \mathrm{M}$ with plasmid DNA pBR322, at $365 \mathrm{~nm}$ for $120 \mathrm{~min}$. Top: Gel electrophoresis picture: Lane 1: DNA without UV irradiation; Lane 2: DNA with UV irradiation; Lanes 3-9: DNA + oxime derivatives (1, 2, 3, 5, 10, 21, and 19, respectively) + UV irradiation; Bottom: Calculation of the \% conversion to ss and ds damage.

Table 1. $\%$ (ss + ds) DNA photocleavage of amidoxime, ethanone oxime and aldoxime derivatives at 312 and $365 \mathrm{~nm}$.

\begin{tabular}{|c|c|c|c|c|c|c|}
\hline Compound & Imine Type ${ }^{1}$ & $\begin{array}{c}\text { Imine } \\
\text { Substituent }\end{array}$ & Conjugate & $\begin{array}{c}312 \text { nm \% (ss + ds) } \\
\text { DNA }^{3} \text { Cleavage } \\
\text { (STDEV) }\end{array}$ & $\begin{array}{c}365 \mathrm{~nm}^{\%}(\mathrm{ss}+\mathrm{ds}) \\
\text { DNA }^{4} \text { Cleavage } \\
\text { (STDEV) }\end{array}$ & $\begin{array}{c}\text { BDE } \\
\text { (kcal/mol) }\end{array}$ \\
\hline 1 & AM & $o$-pyr & $p-\mathrm{NO}_{2} \mathrm{Ph}$ & $90( \pm 4)^{2}$ & $43( \pm 7)$ & 52.81 \\
\hline 2 & AM & $m$-pyr & $p-\mathrm{NO}_{2} \mathrm{Ph}$ & $90( \pm 3)^{2}$ & $79( \pm 7)$ & 51.34 \\
\hline 3 & AM & $p$-pyr & $p-\mathrm{NO}_{2} \mathrm{Ph}$ & $82( \pm 8)^{2}$ & $79( \pm 8)$ & 50.83 \\
\hline 4 & $\mathrm{AM}$ & $p$-MeOPh & $p-\mathrm{NO}_{2} \mathrm{Ph}$ & $30( \pm 10)$ & NUV & 51.13 \\
\hline 5 & AM & $p-\mathrm{NO}_{2} \mathrm{Ph}$ & $p-\mathrm{NO}_{2} \mathrm{Ph}$ & $83( \pm 9)$ & $50( \pm 9)$ & 50.67 \\
\hline 6 & $\mathrm{AM}$ & $o$-pyr & p-pyr & $7( \pm 4)$ & NUV & 52.41 \\
\hline 7 & $\mathrm{AM}$ & $m$-pyr & $p$-pyr & $8( \pm 4)$ & NUV & 51.05 \\
\hline 8 & AM & $p$-pyr & $p$-pyr & $15( \pm 3)$ & NUV & 50.57 \\
\hline 9 & AM & $p$-MeOPh & $p$-pyr & $6( \pm 4)$ & NUV & 50.71 \\
\hline 10 & AM & $p-\mathrm{NO}_{2} \mathrm{Ph}$ & $p$-pyr & $61( \pm 5)$ & $56( \pm 4)$ & 50.51 \\
\hline 11 & $\mathrm{EO}$ & $p$-pyr & $p-\mathrm{NO}_{2} \mathrm{Ph}$ & $90( \pm 5)$ & NUV & 46.07 \\
\hline 12 & EO & $p$-pyr & p-pyr & $84( \pm 7)$ & NUV & 45.89 \\
\hline 13 & AL & $o$-pyr & $p-\mathrm{NO}_{2} \mathrm{Ph}$ & $93( \pm 4)^{2}$ & NUV & 47.18 \\
\hline 14 & AL & $m$-pyr & $p-\mathrm{NO}_{2} \mathrm{Ph}$ & $91( \pm 6)^{2}$ & NUV & 47.18 \\
\hline 15 & AL & $p$-pyr & $p-\mathrm{NO}_{2} \mathrm{Ph}$ & $98( \pm 2)^{2}$ & NUV & 47.00 \\
\hline 16 & $\mathrm{AL}$ & $p$-MeOPh & $p-\mathrm{NO}_{2} \mathrm{Ph}$ & NC & NUV & 47.60 \\
\hline 17 & $\mathrm{AL}$ & $o$-pyr & $p$-pyr & $50( \pm 10)$ & NUV & 46.88 \\
\hline 18 & $\mathrm{AL}$ & $m$-pyr & $p$-pyr & $5( \pm 2)$ & NUV & 46.95 \\
\hline 19 & $\mathrm{AL}$ & $p$-pyr & $p$-pyr & $83( \pm 9)$ & $15( \pm 2)$ & 46.81 \\
\hline 20 & $\mathrm{AL}$ & $p$-MeOPh & p-pyr & $12( \pm 6)$ & NUV & 47.19 \\
\hline 21 & $\mathrm{AL}$ & $p-\mathrm{NO}_{2} \mathrm{Ph}$ & $p$-pyr & $92( \pm 10)$ & 0 & 46.98 \\
\hline
\end{tabular}

${ }^{1} \mathrm{AM}=$ Amidoxime, $\mathrm{EO}=$ Ethanone Oxime, $\mathrm{AL}=$ Aldoxime $;{ }^{2}$ Reference. $[30] ;{ }^{3}$ Plasmid DNA: pBluescipt KS II, $100 \mu \mathrm{M}$ concentration, in DMF; ${ }^{4}$ Plasmid DNA: pBR322, $500 \mu \mathrm{M}$ concentration, in DMF; STDEV = Standard Deviation, $\mathrm{NC}=$ No Cleavage, $\mathrm{NUV}=$ no UV absorption at $365 \mathrm{~nm}, \mathrm{BDE}=$ Bond Dissociation Energy.

In the presence of all compounds (with the exception of 16) the supercoiled plasmid DNA (Form I) sustained at $312 \mathrm{~nm}$ single-stranded (ss) nicks of the double helix, generating the relaxed circular DNA (Form II), whereas in some cases, the linear DNA (Form III), generated by double-stranded (ds) nicks, was formed as well.

Nitro substituted compounds have been studied for their ability to cleave DNA, thus, the $p$-nitrophenyl moiety may also contribute to the observed DNA photocleavage [51-54]. In the case of 
the oxime esters it was evidenced, via photo-chemical experiments, that the aroyloxyl or sulfonyloxyl radicals are the active intermediates for the carboxylic [24-33] or the sulfonic esters [34,35], respectively. Mechanistically, these radicals derive upon the homolysis of the $\mathrm{N}-\mathrm{O}$ bond of the oxime derivatives, as depicted in Scheme 1.

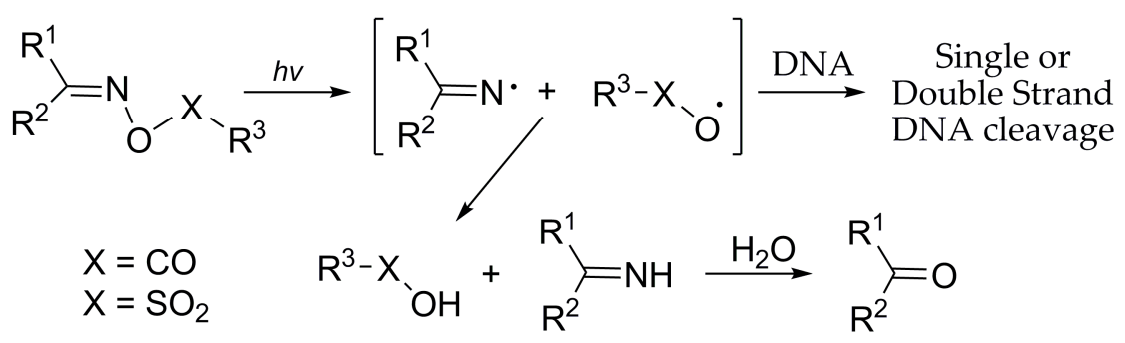

Scheme 1. Photo-cleavage of the N-O bond of oxime ester conjugates.

However, the much better activity of the $p-\mathrm{NO}_{2}$-benzoyl conjugates, found for the series of pyridine aldoximes and amidoximes [30], prompted us to further clarify the issue of the active component by synthesizing and performing DNA photocleavage experiments of additional oxime derivatives. This approach could provide an initial insight based on the structure-activity relationships. In order to further support our study, besides photocleavage experiments, we have designed and performed DNA affinity studies (vide infra) and we have calculated the bond dissociation energies (BDEs) of the tested compounds.

Thus, regarding the oxime series bearing a $p-\mathrm{NO}_{2}$-benzoyl conjugate (compounds 1-5, 11, 13-16) all compounds almost completely photocleaved DNA at $312 \mathrm{~nm}$, except the $p$-MeOPh imine-substituted ones (compounds 4 and 16). A possible excitation of the nitro group would have also contributed to DNA photocleavage of the latter compounds, nevertheless, this was not observed. The same may be concluded checking the activity of pyridoyl conjugates 12, 17 and 19, which lack the $p$ - $\mathrm{NO}_{2}$-benzoyl group. The DNA photo-cleavage activity of these compounds was in general comparable to that of the $p$ - $\mathrm{NO}_{2}$-benzoyl conjugates (12 vs. $\mathbf{1 1}, \mathbf{1 9}$ vs. 15). Additionally, in the cases where the $p$ - $\mathrm{NO}_{2}$-phenyl group was present as the oxime substituent, no substantial enhancement of the DNA photocleavage was observed ( 5 vs. 1 or 2 or 3, 21 vs. 19). Thus, the above described experimental results indicate that $\mathrm{N}-\mathrm{O}$ bond homolysis occurs, as it had been observed by the analysis of the chemically induced photo-cleavage of compound 1 [30]. However, involvement of other factors, like oxygen or secondary excitation reactions cannot be excluded. Theoretical calculations concerning the excitation states of such compounds and mechanistic insights are in due course.

In the amidoxime series, the pyridoyl conjugates (compounds 6-10) do not seem to follow the same trend, at this concentration. However, we cannot explain this lack of activity either by comparing the energies of the $\mathrm{N}-\mathrm{O}$ bonds, or the binding affinities (vide infra), or the UV absorption spectra (SM). The same applies for the $p$-MeOPh oxime substrates (compounds 4, 9, 16 and 20) as well. A possible explanation is that under the conditions applied, these compounds do not efficiently saturate DNA, or that in-cage reactions affect the outcome of the DNA photo-cleavage. Such reactions have been observed in the photo-cleavage of oximes [24,56]. Nevertheless, comparing compounds $\mathbf{6 - 1 0}$ with the respective aldoxime series 17-21, the approximately 5-6 Kcal/mol lower N-O bond energies and/or the better binding constants $\left(\mathrm{K}_{\mathrm{b}}\right)$ and intercalation (vide infra) of the latter may serve as the reason of their higher DNA photo-cleaving activity (8 vs. 19, 10 vs. 21).

Pearson was the first to point out the existence of a relation between the ground state bond strength $\left(\mathrm{D}_{0}\right)$ and excitation energy in diatomic molecules, in 1988 [57]. Since then this concept was extended to polyatomic molecules using a variety of quantum chemical methods showing not only relations between $D_{0}$ and the bond dissociation energy in an excited state $\left(D_{0}{ }^{T 1}\right.$ : BDE in the first excited triplet state), but also relations concerning the activation energy in an excited state and the rate constant $\left(k_{r}\right)$ of a photochemical reaction (e.g., $D_{0}^{T 1}=\alpha_{1}+\beta_{1} \cdot D_{0}$ or $\left.E_{a}^{T 1}=\alpha_{2}+\beta_{2} \cdot D_{0}^{T 1}\right)$ [58-60]. 
This linear correlation between $\mathrm{D}_{0}$ and $\mathrm{D}_{0}{ }^{\mathrm{T} 1}$ prompted us to study whether BDE may be used in our case as an indication for the cleavage ability, upon dissociation, of the oxime esters. Although the DNA photo-cleavage is a very complex phenomenon, which does not allow us for the moment to extract any equation, it seems that, in general, the higher the BDE the lower the \% DNA photo-cleavage, Figure 5.

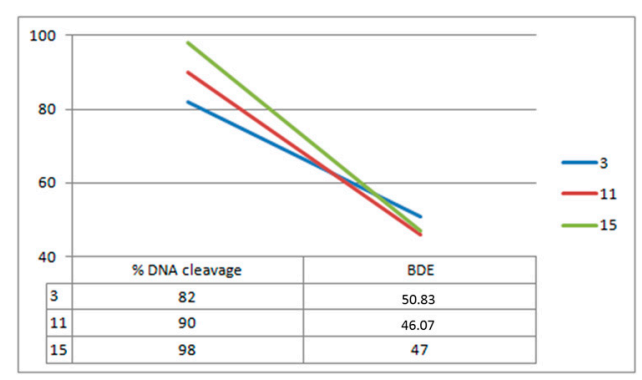

(A)

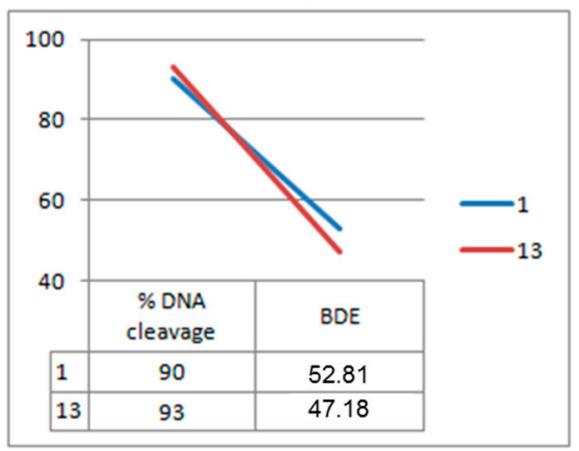

(C)

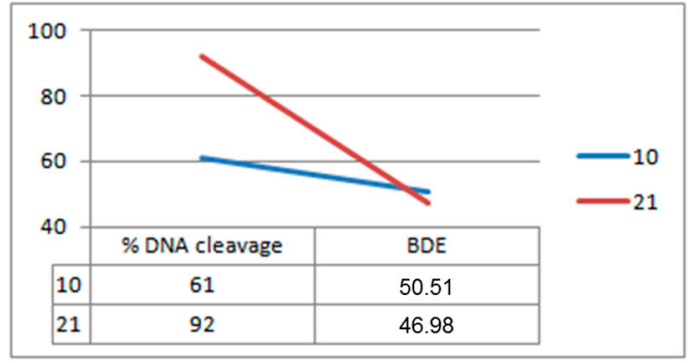

(B)

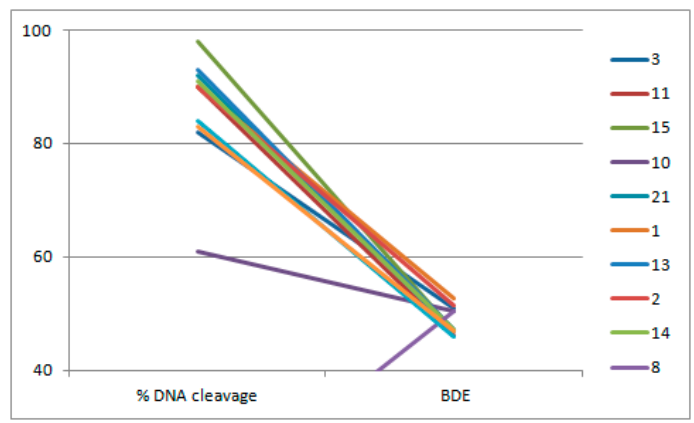

(D)

Figure 5. Graphical correlations between BDE and \% DNA photo-cleavage. (A) Compounds bearing $p$-pyridine oxime substituent and $p$-nitro-phenyl ester conjugate in amidoxime, ethanone oxime and aldoxime (3, 11 and 15, respectively); (B) Compounds bearing $p$-nitro-phenyl oxime substituent and $p$-pyridine ester conjugate in amidoxime and aldoxime (10 and 21, respectively); (C) Compounds bearing $o$-pyridine oxime substituent and $p$-nitro-phenyl ester conjugate in amidoxime and aldoxime (1 and 13, respectively); (D) All DNA photo-cleaving compounds.

Finally, based on the presented results, we may suggest that $p$-pyridine and $p-\mathrm{NO}_{2} \mathrm{Ph}$ oxime substituents favor the right geometry for $\mathrm{H}$ abstraction from DNA, something which was also evidenced for the sulfonyl amidoxime series [35]. The latter phenomenon has been recently studied for another sensitizer (benzophenone) [61].

At $365 \mathrm{~nm}$ amidoximes $\mathbf{3}$ and $\mathbf{1 0}$ seem to retain most of their efficacy, whereas compounds 1, 2, 519 and 21 exhibit less activity. This result could be attributed to the lower UV absorption of the compounds at this wavelength (SM). Nevertheless the observed DNA photo-cleavage proves that the homolysis of the N-O bond may also occur upon UVA irradiation, as it was presented in other cases $[24,27,31-33]$.

The promising DNA photo-cleavage activities observed for the oxime esters bearing $p$-pyridyl and $p-\mathrm{NO}_{2} \mathrm{Ph}$ moieties as both oxime substituents and ester conjugates, prompted us to further study their behavior towards DNA with CT-DNA binding affinities. These studies (following paragraphs) were expected to shed light to the interaction mode.

\subsection{DNA Affinity Studies}

The interaction of compounds 1-16, 19 and $\mathbf{2 1}$ with CT DNA was investigated directly by UV spectroscopy and viscosity measurements and indirectly by the evaluation of the EB-displacing ability of the compounds as examined by fluorescence emission spectroscopy. 


\subsubsection{DNA-Binding Studies with UV Spectroscopy}

The interaction of compounds with CT DNA was initially studied by UV spectroscopy in order to obtain preliminary information in regard to the existence of any interaction and its possible mode and to further calculate the DNA-binding constants of the compounds $\left(\mathrm{K}_{\mathrm{b}}\right)$. Therefore, the UV spectra of a CT DNA solution were recorded in the presence of the compounds at increasing amounts (for different $r$ values) as well as the UV spectra of the compounds in the presence of increasing amounts of CT DNA. The existence of any interaction may perturb the CT DNA band located at $258-260 \mathrm{~nm}$ in the former study or the transition bands of the compounds in the latter study during the titrations providing, thus, initial information of such interaction.

The CT DNA band located at $\lambda_{\max }=257-258 \mathrm{~nm}$ in the UV spectra of a CT DNA solution exhibited in the presence of the compounds either a slight hyperchromism (as representatively in the presence of compound 1, Figure 6A) or a slight hypochromism (as representatively in the presence of compound 3, Figure 6B) which was accompanied by a red-shift up to $262 \mathrm{~nm}$ in most cases. Quite similar features were observed in the UV spectra of CT DNA in the presence of the other compounds. Such changes in the UV spectra of CT DNA may reveal the interaction of the compounds with CT DNA which results in the formation of a new compound-DNA conjugate [62] with a simultaneous stabilization of the CT DNA duplex [63].


Figure 6. UV spectra of CT DNA in buffer solution ( $150 \mathrm{mM} \mathrm{NaCl}$ and $15 \mathrm{mM}$ trisodium citrate at $\mathrm{pH} 7.0$ ) in the absence or presence of increasing amounts of (A) compound $\mathbf{1}$ ([DNA] $=0.155 \mathrm{mM}$ ) and $(B)$ compound $3([D N A]=0.147 \mathrm{mM})$. The arrows show the changes with increasing amounts of the compounds.

The UV spectra of the compounds were recorded in the presence of increasing amounts of a CT DNA solution (diverse $r^{\prime}$ values) and are shown representatively for compounds 5, 9, 12, 15 and 19 in Figure 7 and Figure S4. In the UV spectra of the compounds, one UV band is initially observed (band I) in the range 263-299 nm which shows in the presence of increasing amounts of CT DNA a slight hypochromism.

Furthermore, the band shows in some cases a slight blue- or red-shift up to $3 \mathrm{~nm}$. The existing spectroscopic features observed in the UV spectra of the compounds in the presence of CT DNA are indicative of the interaction of the compounds with CT DNA. Nevertheless, the extent of the observed hypochromism in the UV spectra of the compounds is not so pronounced that safe conclusions concerning the possible complex-DNA interaction mode may be arisen only from the existing UV spectroscopic data [64]; therefore, DNA-viscosity measurements were carried out in an attempt to better clarify the interaction mode. 

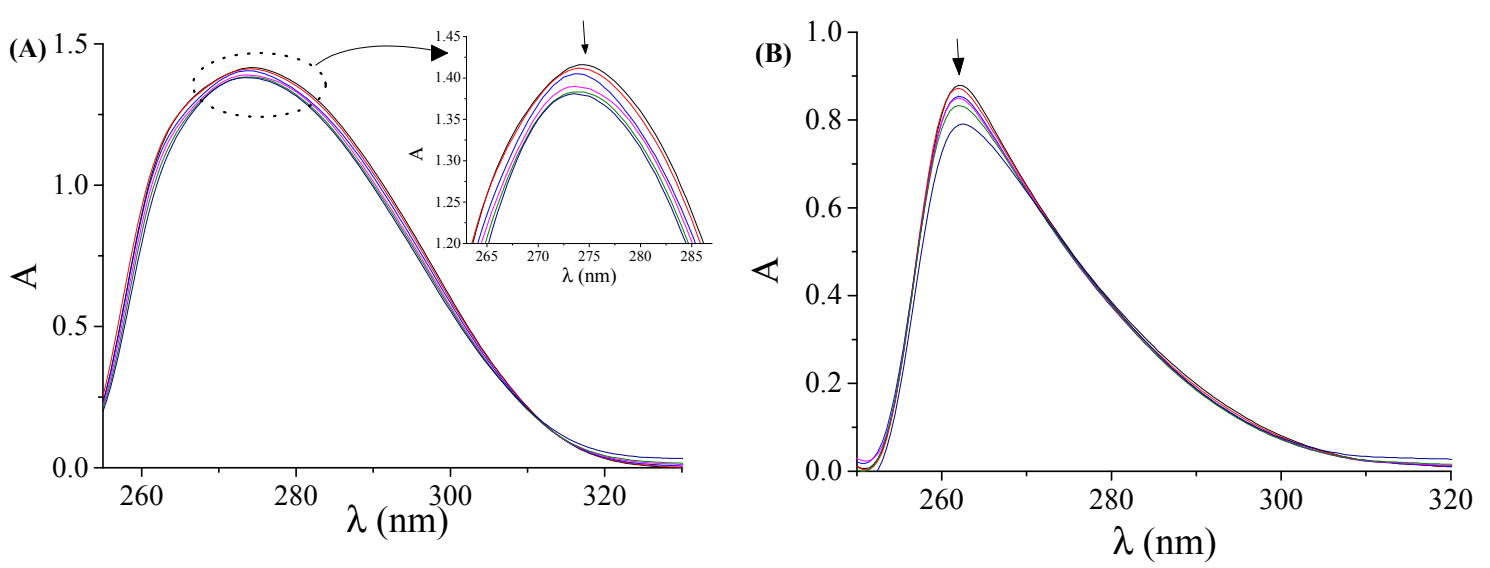

Figure 7. UV spectra of DMSO solution of compound (A) $9\left(2 \times 10^{-5} \mathrm{M}\right)$ and $(\mathbf{B}) \mathbf{1 9}\left(1 \times 10^{-4} \mathrm{M}\right)$ in the presence of increasing amounts of CT DNA $\left(\mathrm{r}^{\prime}=[\mathrm{DNA}] /[\right.$ compound $\left.]=0-0.8\right)$. The arrows show the changes upon increasing amounts of CT DNA.

The DNA-binding constants $\left(K_{b}\right)$ of the compounds (Table 2) were determined by the Wolfe-Shimer equation (Equation (3)) [65] and the plots [DNA] $/\left(\varepsilon_{\mathrm{A}}-\varepsilon_{\mathrm{f}}\right)$ versus [DNA] (representatively shown in Figure S5). In brief, the $\mathrm{K}_{\mathrm{b}}$ constants of the compounds are relatively high with compound 21 bearing the highest $\mathrm{K}_{\mathrm{b}}$ constant $\left(=1.85( \pm 0.18) \times 10^{6} \mathrm{M}^{-1}\right)$ among the studied compounds. The $\mathrm{K}_{\mathrm{b}}$ constants of most of the compounds are higher than that of the classical intercalator EB $\left(=1.23( \pm 0.07) \times 10^{5} \mathrm{M}^{-1}\right)$ as it was previously calculated [66]. Furthermore, the $\mathrm{K}_{\mathrm{b}}$ constants of these compounds bear values similar to those recently reported for sulfonyl ketoximes [34] and sulfonyl amidoximes [35].

Table 2. UV spectral features of the interaction of selected compounds 1-16, 19 and 21 with CT DNA; $\mathrm{UV}$-band $(\lambda, \mathrm{nm})$ (percentage of observed hyper-/hypo-chromism $\left(\Delta \mathrm{A} / \mathrm{A}_{0}, \%\right)$, blue-/red-shift of the $\left.\lambda_{\max }(\Delta \lambda, \mathrm{nm})\right)$ and DNA-binding constants $\left(\mathrm{K}_{\mathrm{b}}, \mathrm{M}^{-1}\right)$.

\begin{tabular}{ccc}
\hline Compound & Band $(\mathbf{n m})\left(\Delta \mathbf{A} / \mathbf{A o}(\mathbf{\%})^{\mathbf{1}}, \Delta \lambda(\mathbf{n m})\right)^{\mathbf{2}}$ & $\left.\mathbf{K}_{\mathbf{b}} \mathbf{( M}^{\mathbf{- 1}}\right)$ \\
\hline $\mathbf{1}$ & $272(-2.0,0)$ & $1.62( \pm 0.18) \times 10^{6}$ \\
$\mathbf{2}$ & $266(-7.0,0)$ & $2.06( \pm 0.04) \times 10^{5}$ \\
$\mathbf{3}$ & $267(-2.5,+2)$ & $3.73( \pm 0.27) \times 10^{4}$ \\
$\mathbf{4}$ & $265(-3.0,+3)$ & $5.88( \pm 0.41) \times 10^{4}$ \\
$\mathbf{5}$ & $273(-1.5,-1)$ & $1.25( \pm 0.29) \times 10^{6}$ \\
$\mathbf{6}$ & $277(-1.0,0)$ & $3.90( \pm 0.16) \times 10^{5}$ \\
$\mathbf{7}$ & $273(-1.0,0)$ & $1.59( \pm 0.16) \times 10^{6}$ \\
$\mathbf{8}$ & $264(-5.0,+2)$ & $3.60( \pm 0.17) \times 10^{5}$ \\
$\mathbf{9}$ & $275(-2.5,0)$ & $7.31( \pm 0.16) \times 10^{5}$ \\
$\mathbf{1 0}$ & $272(-2.5,0)$ & $1.52( \pm 0.10) \times 10^{5}$ \\
$\mathbf{1 1}$ & $272(-1.0,0)$ & $4.79( \pm 0.08) \times 10^{4}$ \\
$\mathbf{1 2}$ & $274(-12.0,-3)$ & $6.02( \pm 0.17) \times 10^{5}$ \\
$\mathbf{1 3}$ & $268(-5.0,+1)$ & $3.04( \pm 0.22) \times 10^{5}$ \\
$\mathbf{1 4}$ & $272(-2.0,0)$ & $8.50( \pm 0.27) \times 10^{5}$ \\
$\mathbf{1 5}$ & $267(-2.5,+1)$ & $3.23( \pm 0.03) \times 10^{5}$ \\
$\mathbf{1 6}$ & $277(+1.0,0)$ & $3.47( \pm 0.27) \times 10^{5}$ \\
$\mathbf{1 9}$ & $263(-10.0,0)$ & $1.29( \pm 0.09) \times 10^{6}$ \\
$\mathbf{2 1}$ & $265(-6.0,0)$ & $1.85( \pm 0.18) \times 10^{6}$ \\
\hline
\end{tabular}

1 “" denotes hyperchromism, " -" denotes hypochromism; " "+" denotes red-shift, " -" denotes blue-shift. 


\subsubsection{DNA-Binding Study with Viscosity Measurements}

The interaction of the selected compounds (i.e., 1-16, 19 and 21) with CT DNA was also monitored through the changes of DNA-viscosity upon addition of the compounds. The measurement of the DNA-viscosity of DNA is among the most reliable techniques and may provide significant aid to clarify the interaction mode of a compound with DNA, since it is sensitive to such DNA-length changes [67]; more specifically, the relative DNA-viscosity $\left(\eta / \eta_{0}\right)$ is sensitive to the relative DNA-length changes $\left(\mathrm{L} / \mathrm{L}_{0}\right)$ occurring in the presence a DNA-binder and are correlated by the equation $\mathrm{L} / \mathrm{L}_{0}=\left(\eta / \eta_{0}\right)^{1 / 3}[67]$. In general, upon binding of a compound to DNA via intercalation, the separation distance of the DNA-base pairs located at the intercalation sites will exhibit an increase in order to host the compound inserting in-between the DNA-base pairs and, subsequently, the relative DNA-length will also increase and lead to an increase of DNA-viscosity, the magnitude of which is usually in accordance to the strength of the interaction [68]. On the other hand, in the case of non-intercalation (i.e., electrostatic interaction or external groove-binding), the binding of a compound to DNA grooves will induce a bend or kink in the DNA helix leading rather to slight shortening of the relative DNA-length which may be revealed via a slight decrease of the DNA-viscosity [68].

Within this context, the viscosity of a CT DNA solution $(0.1 \mathrm{mM})$ was monitored upon addition of increasing amounts of the compounds (up to the value of $r=0.35$ ). Initially and up to $r$ value of 0.1 , the viscosity of CT DNA exhibit a decrease in the presence of most compounds and for higher concentrations, the DNA-viscosity presented a noteworthy increase (Figure 8).
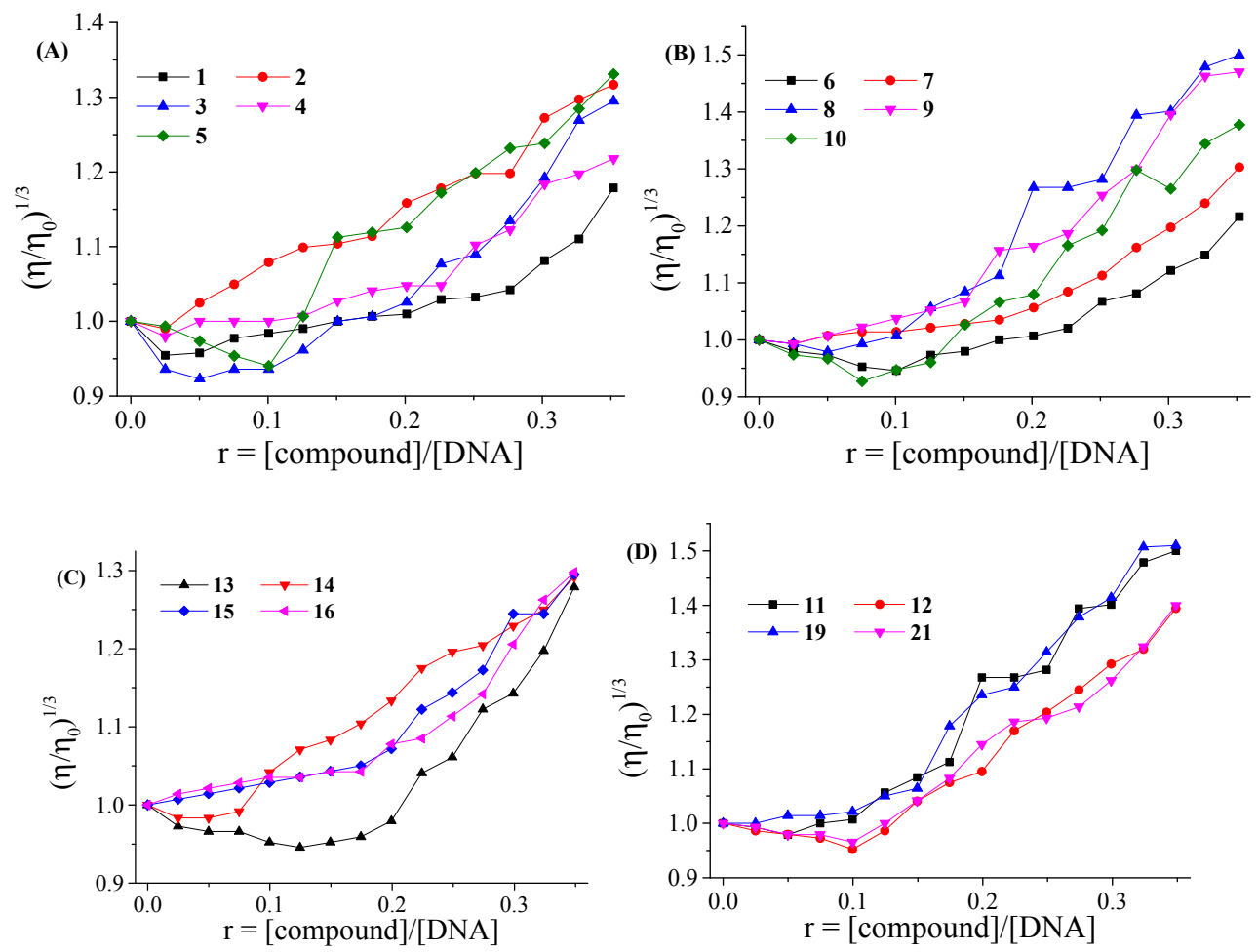

Figure 8. Relative viscosity $\left(\eta / \eta_{\mathrm{o}}\right)^{1 / 3}$ of CT DNA $(0.1 \mathrm{mM})$ in buffer solution $(150 \mathrm{mM} \mathrm{NaCl}$ and $15 \mathrm{mM}$ trisodium citrate at $\mathrm{pH}$ 7.0) in the presence of compounds (A) 1-5, (B) 6-10, (C) 13-16 and (D) 11, 12, 19 and 21 at increasing amounts $(r=$ [compound $] /[\mathrm{DNA}])$.

Considering the overall changes of the DNA-viscosity in the presence of the compounds tested, we may suggest that they initially interact to CT DNA probably by non-classical intercalation (i.e., as groove-binders) so as to closely approach to DNA. Afterwards and as a subsequent step, they may intercalate within the CT DNA base pairs. Such behaviour may better clarify and justify the findings from the UV spectroscopic studies. 


\subsubsection{EB-Displacement Studies with Fluorescence Emission Spectroscopy}

The ability of the compounds to displace EB from the EB-DNA complex may further clarify and verify indirectly their intercalating ability. $\mathrm{EB}$ is a known fluorescence dye and is a typical indicator of DNA-intercalation [69] which takes place via the insertion of its planar phenanthridine ring in-between the DNA base pairs. The formed EB-DNA conjugate exhibits an intense fluorescence emission band at $592-593 \mathrm{~nm}$, when excited at $540 \mathrm{~nm}$. The addition of another intercalating compound may induce quenching of this emission band $[69,70]$.

The EB-DNA conjugate was prepared via the pre-treatment of an EB solution ([EB] $=20 \mu \mathrm{M})$ with CT DNA ([DNA] $=26 \mu \mathrm{M})$ for $\sim 1 \mathrm{~h}$. The fluorescence emission spectra $\left(\lambda_{\mathrm{ex}}=540 \mathrm{~nm}\right)$ of this EB-DNA solution were recorded in the presence of increasing amounts of the compounds (representatively shown for compound $\mathbf{1}$ in Figure S6). In brief, the addition of the compounds in the EB-DNA solution resulted in a moderate-to-significant quenching of the DNA-EB emission band at $592 \mathrm{~nm}$ (Figure 9); the final quenching $(\Delta \mathrm{I} / \mathrm{Io})$ is in the range $51.4 \%-77.4 \%$ of the initial EB-DNA fluorescence (Table 3$)$. Thus, the extent of the observed quenching may reveal that the compounds have the potential to displace EB from the EB-DNA conjugate as a result of the competition with EB when binding to the DNA intercalation sites; thus we may indirectly conclude the existence of intercalation of the complexes to CT DNA [71].
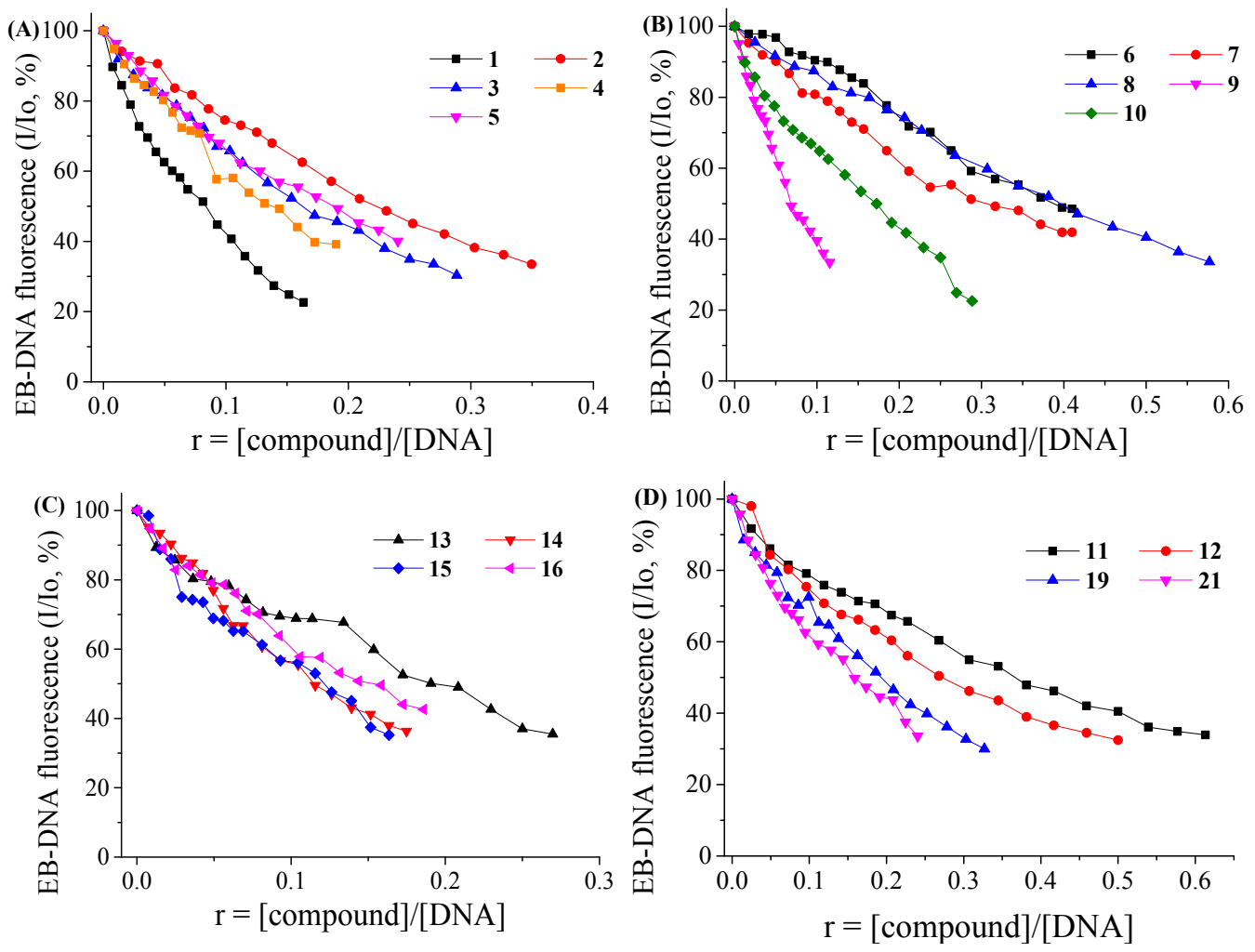

Figure 9. Plot of EB-DNA relative fluorescence emission intensity (\%I/Io) at $\lambda_{\mathrm{em}}=592 \mathrm{~nm}$ vs. $r$ $(r=$ [compound]/[DNA]) in buffer solution (150 mM NaCl and $15 \mathrm{mM}$ trisodium citrate at $\mathrm{pH} 7.0)$ in the presence of compounds (A) 1-5 (quenching up to $22.6 \%$ of the initial EB-DNA fluorescence for 1, 33.5 for 2, 30.4\% for 3, 39.8\% for 4 and 40.1\% for 5); (B) 6-10 (quenching up to $48.6 \%$ of the initial EB-DNA fluorescence for $\mathbf{6 , 4 1 . 9 \%}$ for $\mathbf{7}, 33.6 \%$ for $\mathbf{8}, 33.4 \%$ for $\mathbf{9}$ and $\mathbf{2 2 . 6 \%}$ for $\mathbf{1 0}$ ); (C) $\mathbf{1 3}-\mathbf{1 6}$ (quenching up to $35.5 \%$ of the initial EB-DNA fluorescence for 13, 36.3\% for 14, 35.2\% for 15 and $42.6 \%$ for 16); (D) 11, 12, 19 and 21 (quenching up to 33.9\% of the initial EB-DNA fluorescence for 11, 32.5\% for 12, $30.0 \%$ for 19 and $33.6 \%$ for 21 ). 
Table 3. Data of the EB-competitive studies of selected compounds. Percentage of EB-DNA fluorescence quenching $(\Delta \mathrm{I} / \mathrm{Io}, \%)$, Stern-Volmer constants $\left(\mathrm{K}_{\mathrm{SV}}, \mathrm{M}^{-1}\right)$ and quenching constants $\left(\mathrm{k}_{\mathrm{q}}, \mathrm{M}^{-1} \mathrm{~s}^{-1}\right)$.

\begin{tabular}{|c|c|c|c|}
\hline Compound & $\Delta \mathrm{I} / \mathrm{Io}(\%)$ & $K_{s v}\left(M^{-1}\right)$ & $k_{q}\left(M^{-1} s^{-1}\right)$ \\
\hline 1 & 77.4 & $1.94( \pm 0.05) \times 10^{5}$ & $8.43( \pm 0.20) \times 10^{12}$ \\
\hline 2 & 66.5 & $8.27( \pm 0.27) \times 10^{4}$ & $3.60( \pm 0.12) \times 10^{12}$ \\
\hline 3 & 69.6 & $1.80( \pm 0.05) \times 10^{5}$ & $7.82( \pm 0.22) \times 10^{12}$ \\
\hline 4 & 60.2 & $1.34( \pm 0.05) \times 10^{5}$ & $5.82( \pm 0.21) \times 10^{12}$ \\
\hline 5 & 59.9 & $1.20( \pm 0.03) \times 10^{5}$ & $5.20( \pm 0.11) \times 10^{12}$ \\
\hline 6 & 51.4 & $4.46( \pm 0.15) \times 10^{4}$ & $1.94( \pm 0.07) \times 10^{12}$ \\
\hline 7 & 58.1 & $6.08( \pm 0.14) \times 10^{4}$ & $2.64( \pm 0.06) \times 10^{12}$ \\
\hline 8 & 66.4 & $6.85( \pm 0.25) \times 10^{4}$ & $2.98( \pm 0.11) \times 10^{12}$ \\
\hline 9 & 66.6 & $3.23( \pm 0.11) \times 10^{5}$ & $1.40( \pm 0.05) \times 10^{13}$ \\
\hline 10 & 77.4 & $1.50( \pm 0.05) \times 10^{5}$ & $6.52( \pm 0.20) \times 10^{12}$ \\
\hline 11 & 66.1 & $7.15( \pm 0.16) \times 10^{4}$ & $3.11( \pm 0.07) \times 10^{12}$ \\
\hline 12 & 67.5 & $1.06( \pm 0.03) \times 10^{5}$ & $4.60( \pm 0.11) \times 10^{12}$ \\
\hline 13 & 64.5 & $1.25( \pm 0.03) \times 10^{5}$ & $5.43( \pm 0.12) \times 10^{12}$ \\
\hline 14 & 63.4 & $1.53( \pm 0.04) \times 10^{5}$ & $6.65( \pm 0.16) \times 10^{12}$ \\
\hline 15 & 64.7 & $3.11( \pm 0.06) \times 10^{5}$ & $1.35( \pm 0.03) \times 10^{13}$ \\
\hline 16 & 57.4 & $1.24( \pm 0.04) \times 10^{5}$ & $5.40( \pm 0.15) \times 10^{12}$ \\
\hline 19 & 70.0 & $7.27( \pm 0.19) \times 10^{4}$ & $3.16( \pm 0.08) \times 10^{12}$ \\
\hline 21 & 66.4 & $1.33( \pm 0.02) \times 10^{5}$ & $5.80( \pm 0.07) \times 10^{12}$ \\
\hline
\end{tabular}

The quenching of the EB-DNA fluorescence induced by the compounds was found to be in good agreement $(R=0.99)$ with the linear Stern-Volmer equation (Equation (4)) [69] as indicated in the corresponding Stern-Volmer plots (shown in Figures S7 and S8). The $\mathrm{K}_{\mathrm{SV}}$ constants of the compounds (Table 3) are moderate-to-high verifying their binding affinity for DNA, with compounds 9 and 15 bearing the highest $\mathrm{K}_{\mathrm{SV}}$ constants among the compounds. Based on the value of $\tau_{\mathrm{o}}=23 \mathrm{~ns}$ as the fluorescence lifetime of EB-DNA system [72], the quenching constants of the compounds were calculated with Equation (4). The $\mathrm{k}_{\mathrm{q}}$ constants of the compounds (Table 3) are significantly higher than $10^{10} \mathrm{M}^{-1} \cdot \mathrm{s}^{-1}$ suggesting, thus, the quenching of the EB-DNA fluorescence takes place via a static mechanism [71].

\section{Materials and Methods}

\subsection{General Information}

All commercially available reagent-grade chemicals and solvents were used without further purification. Dry solvents were prepared by literature methods and stored over molecular sieves. CT DNA, EB, NaCl and trisodium citrate were purchased from Sigma-Aldrich Co. (Schnelldorf, Germany). CT DNA stock solution was prepared by dilution of CT DNA to buffer (containing $15 \mathrm{mM}$ trisodium citrate and $150 \mathrm{mM} \mathrm{NaCl}$ at $\mathrm{pH}$ 7.0) followed by 3 days stirring and kept at $4{ }^{\circ} \mathrm{C}$ for no longer than two weeks. The stock solution of CT DNA gave a ratio of UV absorbance at 260 and $280 \mathrm{~nm}\left(\mathrm{~A}_{260} / \mathrm{A}_{280}\right)$ of 1.85-1.88, indicating that the DNA was sufficiently free of protein contamination [73]. The CT DNA concentration was determined by the UV absorbance at $260 \mathrm{~nm}$ after 1:20 dilution using $\varepsilon=6600 \mathrm{M}^{-1} \mathrm{~cm}^{-1}$ [74]. pBluescipt KS II plasmid DNA purification was performed using the Nucleospin plasmid kit, according to the protocol provided by the manufacturer (Macherey-Nagel, Duren, Germany). pBR322 was purchased from New England BioLabs (Ipswich, MA, USA).UV-visible (UV-vis) spectra were recorded on a U-2001 dual beam spectrophotometer (Hitachi, Tokyo, Japan). Fluorescence emission spectra were recorded in solution on a Hitachi F-7000 fluorescence spectrophotometer (Hitachi, Tokyo, Japan). Viscosity experiments were carried out using an ALPHA L Fungilab rotational viscometer (Fungilab, Barcelona, Spain) equipped with an $18 \mathrm{~mL}$ LCP spindle and the measurements were performed at $100 \mathrm{rpm}$. Samples containing pBluescipt KS II plasmid DNA were irradiated in a Macrovue 2011 transilluminator (LKB Produkter, Bromma, Sweden) 
at $312 \mathrm{~nm}, \mathrm{~T}-15 . \mathrm{M} 90 \mathrm{~W}, 0.225 \mathrm{~W} / \mathrm{cm}^{2}, 10 \mathrm{~cm}$ distance. Samples containing pBR322 plasmid DNA were irradiated with Actinic BL PL-S 9W/10/2P lamps $(2 \times 9$ W, Philips, Pila, Poland $)$ at $365 \mathrm{~nm}$, $5 \mathrm{~cm}$ distance.

Mps were measured on a Kofler hot-stage apparatus or a M5000 melting point meter (KRÜSS, Hamburg, Germany) and are uncorrected. FT-IR spectra were obtained in a Nicolet FT-IR 6700 spectrophotometer(Thermo Fisher Scientific, Madison, WI, USA) using potassium bromide pellets. NMR spectra (500 MHz and $125 \mathrm{MHz}$ for ${ }^{1} \mathrm{H}$ and ${ }^{13} \mathrm{C}$, respectively) were recorded on an Agilent 500/54 spectrometer (Agilent Technologies, Santa Clara, CA, USA) using $\mathrm{CDCl}_{3}$, and/or DMSO- $d_{6}$ as solvent. $J$ values are reported in Hz. High resolution mass spectra (HRMS) were recorded on micrOTOF GC-MS QP 5050 single-quadrupole mass spectrometer (Shimadzu, LTQ ORBITRAP XL with ETD- Thermo Fisher Scientific, San Jose, CA, USA and Bremen, Germany). All reactions were monitored on commercial available pre-coated TLC plates (layer thickness $0.25 \mathrm{~mm}$ ) of Kieselgel $60 \mathrm{~F}_{254}$. Yields were calculated after recrystallization.

\subsection{Synthesis: General Procedure for the Synthesis of Oxime Ester Conjugates}

Parent amidoxime, ethanone oxime or aldoxime $(2 \mathrm{mmol})$ was dissolved in THF or $\mathrm{CHCl}_{3}$ $(0.15 \mathrm{M})$ and $\mathrm{Et}_{3} \mathrm{~N}$ or DIPEA $(2.2 \mathrm{mmol})$ was added at $0{ }^{\circ} \mathrm{C}$ under an Ar atmosphere, followed by the corresponding acid chloride (2.2 mmol). $p$-Pyridoyl chloride was commercially available as an $\mathrm{HCl}$ salt, therefore in those cases the amount of the amine used was doubled. The temperature was allowed to slowly rise to $25^{\circ} \mathrm{C}$. The reaction was monitored by TLC and, upon completion, water $(100 \mathrm{~mL})$ was added and the mixture was extracted with dichloromethane $(2 \times 100 \mathrm{~mL})$. The organic layers were further washed with water $(100 \mathrm{~mL})$, dried with $\mathrm{Na}_{2} \mathrm{SO}_{4}$, and the solvents were evaporated to dryness. The crude residue was then recrystallized, unless otherwise mentioned, to give the desired product, which was found to be sufficiently pure.

(Z)-N'-((4-Nitrobenzoyl)oxy)picolinimidamide (1). Prepared according to reference [30]. ${ }^{1} \mathrm{H}-\mathrm{NMR}$ $\left(\right.$ DMSO- $\left.d_{6}\right) \delta 8.69(\mathrm{~d}, J=4.4 \mathrm{~Hz}, 1 \mathrm{H}), 8.47(\mathrm{~d}, J=8.7 \mathrm{~Hz}, 2 \mathrm{H}), 8.34(\mathrm{~d}, J=8.7 \mathrm{~Hz}, 2 \mathrm{H}), 8.02(\mathrm{~d}$, $J=7.9 \mathrm{~Hz}, 1 \mathrm{H}), 7.96(\mathrm{t}, J=7.1 \mathrm{~Hz}, 1 \mathrm{H}), 7.58(\mathrm{t}, J=5.3 \mathrm{~Hz}, 1 \mathrm{H}), 7.36(\mathrm{br} \mathrm{s}, 1 \mathrm{H}), 7.18(\mathrm{br} \mathrm{s}, 1 \mathrm{H}) \mathrm{ppm}$.

(Z)-N'-((4-Nitrobenzoyl)oxy)nicotinimidamide (2). Prepared according to reference [30]. ${ }^{1} \mathrm{H}-\mathrm{NMR}$ $\left(\right.$ DMSO- $\left.d_{6}\right) \delta 8.94(\mathrm{~d}, J=1.7 \mathrm{~Hz}, 1 \mathrm{H}), 8.72(\mathrm{dd}, J=4.8,1.4 \mathrm{~Hz}, 1 \mathrm{H}), 8.45(\mathrm{~d}, J=8.8 \mathrm{~Hz}, 2 \mathrm{H}), 8.34$ $(\mathrm{d}, J=8.8 \mathrm{~Hz}, 2 \mathrm{H}), 8.14(\mathrm{dt}, J=8.0,1.8 \mathrm{~Hz}, 1 \mathrm{H}), 7.53(\mathrm{dd}, J=7.8,4.8 \mathrm{~Hz}, 1 \mathrm{H}), 7.33(\mathrm{br} \mathrm{s}, 2 \mathrm{H}) \mathrm{ppm}$.

(Z)-N'-((4-Nitrobenzoyl)oxy) isonicotinimidamide (3). Prepared according to reference [30]. ${ }^{1} \mathrm{H}-\mathrm{NMR}$ $\left(\right.$ DMSO- $\left.d_{6}\right) \delta 8.72(\mathrm{dd}, J=6.0,1.4 \mathrm{~Hz}, 2 \mathrm{H}), 8.45(\mathrm{dd}, J=9.0,2.0 \mathrm{~Hz}, 2 \mathrm{H}), 8.35(\mathrm{dd}, J=9.0,2.1 \mathrm{~Hz}, 2 \mathrm{H})$, $7.75(\mathrm{dd}, J=6.0,0.4 \mathrm{~Hz}, 2 \mathrm{H}), 7.36$ (br s, 2H) ppm.

(Z)-4-Methoxy-N'-((4-nitrobenzoyl)oxy)benzimidamide (4). Solvent: THF; R.T.: 12 h; amine: Et 3 N; light yellow crystals, yield $85 \%, \mathrm{mp} 190-192{ }^{\circ} \mathrm{C}$ (ethyl acetate/ethanol); $\mathrm{IR}(\mathrm{KBr}): 3481,3382,1724,1623 \mathrm{~cm}^{-1}$; ${ }^{1} \mathrm{H}-\mathrm{NMR}\left(\mathrm{CDCl}_{3}+\mathrm{DMSO}_{-}{ }_{6}\right) \delta 8.36(\mathrm{~d}, J=7.7 \mathrm{~Hz}, 2 \mathrm{H}), 8.25(\mathrm{~d}, J=7.7 \mathrm{~Hz}, 2 \mathrm{H}), 7.68(\mathrm{~d}, J=7.6 \mathrm{~Hz}, 2 \mathrm{H})$, $6.88(\mathrm{~d}, J=7.6 \mathrm{~Hz}, 2 \mathrm{H}), 6.59(\mathrm{br} \mathrm{s}, 2 \mathrm{H}), 3.78(\mathrm{~s}, 3 \mathrm{H}) \mathrm{ppm} ;{ }^{13} \mathrm{C}-\mathrm{NMR}\left(\mathrm{CDCl}_{3}+\mathrm{DMSO}-d_{6}\right) \delta 161.0,160.0$, 156.2, 148.8, 134.0, 129.5, 127.2, 122.2, 122.0, 112.2, 53.9 ppm; HRMS (ESI) Calc $\mathrm{C}_{15} \mathrm{H}_{14} \mathrm{~N}_{3} \mathrm{O}_{5}[\mathrm{M}+\mathrm{H}]^{+}$ 316.0928; found 316.0925.

(Z)-4-Nitro-N'-((4-nitrobenzoyl)oxy)benzimidamide (5). Solvent: THF; R.T.: 4 h; amine: $\mathrm{Et}_{3} \mathrm{~N}$; light yellow crystals, yield 79\%, mp $243.8^{\circ} \mathrm{C}$ (ethyl acetate); IR (KBr): 3490, 3360, 3111, 1725, $1627 \mathrm{~cm}^{-1}$; ${ }^{1} \mathrm{H}-\mathrm{NMR}$ $\left(\mathrm{CDCl}_{3}+\mathrm{DMSO}_{-} d_{6}\right) \delta 8.45(\mathrm{~d}, J=8.8 \mathrm{~Hz}, 2 \mathrm{H}), 8.29(\mathrm{~d}, J=8.8 \mathrm{~Hz}, 2 \mathrm{H}), 8.27(\mathrm{~d}, J=8.8 \mathrm{~Hz}, 2 \mathrm{H}), 8.04(\mathrm{~d}$, $J=8.8 \mathrm{~Hz}, 2 \mathrm{H}), 7.25$ (br s, $2 \mathrm{H}) \mathrm{ppm} ;{ }^{13} \mathrm{C}-\mathrm{NMR}\left(\mathrm{CDCl}_{3}+\mathrm{DMSO}_{-} \mathrm{d}_{6}\right) \delta 160.2,154.1,148.4,147.0,136.0$, 133.0, 129.3, 126.6, 121.6, 121.5 ppm; HRMS (ESI) Calc $\mathrm{C}_{14} \mathrm{H}_{11} \mathrm{~N}_{4} \mathrm{O}_{6}[\mathrm{M}+\mathrm{H}]^{+} 331.0673$; found 331.0675. 
(Z)-N'-(Isonicotinoyloxy)picolinimidamide (6). Solvent: $\mathrm{CHCl}_{3}$; R.T.: $5 \mathrm{~h}$; amine: DIPEA; white crystals, yield 77\%, mp $161.1^{\circ} \mathrm{C}$ (ethyl acetate); IR (KBr): 3493, 3380, 3054, 1732, $1632 \mathrm{~cm}^{-1} ;{ }^{1} \mathrm{H}-\mathrm{NMR}$ $\left.\left(\mathrm{CDCl}_{3}+\mathrm{DMSO}_{-}\right)_{6}\right) \delta 8.72(\mathrm{dd}, J=4.5,1.5 \mathrm{~Hz}, 2 \mathrm{H}), 8.56(\mathrm{~d}, J=4.6 \mathrm{~Hz}, 1 \mathrm{H}), 8.07(\mathrm{~d}, J=8.0 \mathrm{~Hz}$, $1 \mathrm{H}), 8.00(\mathrm{dd}, J=4.5,1.5 \mathrm{~Hz}, 2 \mathrm{H}), 7.76(\mathrm{dt}, J=7.2,1.6 \mathrm{~Hz}, 1 \mathrm{H}), 7.40(\mathrm{ddd}, J=7.4,4.9,0.9 \mathrm{~Hz}, 1 \mathrm{H}), 6.82$ (br s, 2H) ppm; ${ }^{13} \mathrm{C}-\mathrm{NMR}\left(\mathrm{CDCl}_{3}+\mathrm{DMSO}_{-} d_{6}\right) \delta 161.2,153.5,149.1,147.2,146.5,135.6,135.4,124.4$, 121.7, 119.9 ppm; HRMS (ESI) Calc $\mathrm{C}_{12} \mathrm{H}_{11} \mathrm{~N}_{4} \mathrm{O}_{2}[\mathrm{M}+\mathrm{H}]^{+}$243.0877; found 243.0876.

(Z)-N'-(Isonicotinoyloxy)nicotinimidamide (7). Solvent: $\mathrm{CHCl}_{3}$; R.T.: $3 \mathrm{~h}$; amine: DIPEA; white crystals, yield $73 \%$, mp $155.9^{\circ} \mathrm{C}$ (ethyl acetate); IR (KBr): 3445, 3313, 3166, 1726, $1634 \mathrm{~cm}^{-1}$; ${ }^{1} \mathrm{H}-\mathrm{NMR}(500 \mathrm{MHz}$, $\left.\mathrm{CDCl}_{3}+\mathrm{DMSO}_{-} \mathrm{d}_{6}\right) \delta 8.93(\mathrm{~s}, 1 \mathrm{H}), 8.73(\mathrm{~d}, J=4.7 \mathrm{~Hz}, 2 \mathrm{H}), 8.63(\mathrm{~d}, J=3.3 \mathrm{~Hz}, 1 \mathrm{H}), 8.08(\mathrm{~d}, J=7.9 \mathrm{~Hz}$, $1 \mathrm{H}), 8.02(\mathrm{~d}, J=5.5 \mathrm{~Hz}, 2 \mathrm{H}), 7.37(\mathrm{dd}, J=7.6,4.9 \mathrm{~Hz}, 1 \mathrm{H}), 7.00(\mathrm{br} \mathrm{s}, 2 \mathrm{H}) \mathrm{ppm} ;{ }^{13} \mathrm{C}-\mathrm{NMR}(125 \mathrm{MHz}$, $\mathrm{CDCl}_{3}+$ DMSO- $d_{6}$ ) $\delta 161.0,154.5,149.8,148.9,146.6,135.2,133.3,126.2,121.7,121.5$ ppm; HRMS (ESI) Calc $\mathrm{C}_{12} \mathrm{H}_{11} \mathrm{~N}_{4} \mathrm{O}_{2}[\mathrm{M}+\mathrm{H}]^{+}$243.0877; found 243.0872.

(Z)- $\mathrm{N}^{\prime}$-(Isonicotinoyloxy)isonicotinimidamide (8). Solvent: $\mathrm{CHCl}_{3}$; R.T.: $3 \mathrm{~h}$; amine: $\mathrm{Et}_{3} \mathrm{~N}$; column chromatography $\left(10 \% \mathrm{MeOH}\right.$ in ethyl acetate); Light yellow crystals, yield $70 \%$, mp $155{ }^{\circ} \mathrm{C}$ (ethyl acetate); IR (KBr): 3459, 3366, 1731, $1627 \mathrm{~cm}^{-1} ;{ }^{1} \mathrm{H}-\mathrm{NMR}$ (DMSO- $\left.d_{6}\right) \delta 8.82(\mathrm{dd}, J=4.2,1.3 \mathrm{~Hz}, 2 \mathrm{H}$ ), $8.72(\mathrm{dd}, J=4.4,1.3 \mathrm{~Hz}, 2 \mathrm{H}), 8.09(\mathrm{dd}, J=4.4,1.6 \mathrm{~Hz}, 2 \mathrm{H}), 7.74(\mathrm{dd}, J=4.5,1.6 \mathrm{~Hz}, 2 \mathrm{H}), 7.32(\mathrm{br} \mathrm{s}, 2 \mathrm{H})$ ppm; ${ }^{13}$ C-NMR (DMSO- $d_{6}$ ) $\delta 162.4,155.7,150.6,150.1,139.0,136.3,122.9,121.2$ ppm; HRMS (ESI) Calc $\mathrm{C}_{12} \mathrm{H}_{11} \mathrm{~N}_{4} \mathrm{O}_{2}[\mathrm{M}+\mathrm{H}]^{+}$243.0877; found 243.0872.

(Z)-N'-(Isonicotinoyloxy)-4-methoxybenzimidamide (9). Solvent: THF; R.T.: 7 h; amine: $\mathrm{Et}_{3} \mathrm{~N}$; white crystals, yield $87 \%$, mp $165.8^{\circ} \mathrm{C}$ (ethyl acetate); IR (KBr): 3492, 3366, 1728, $1618 \mathrm{~cm}^{-1} ;{ }^{1} \mathrm{H}-\mathrm{NMR}$ $\left(\mathrm{CDCl}_{3}+\mathrm{DMSO}_{-} d_{6}\right) \delta 8.49(\mathrm{~d}, J=5.9 \mathrm{~Hz}, 2 \mathrm{H}), 7.66(\mathrm{~d}, J=6.0 \mathrm{~Hz}, 2 \mathrm{H}), 7.45(\mathrm{~d}, J=8.9 \mathrm{~Hz}, 2 \mathrm{H}), 6.63(\mathrm{~d}$, $J=8.9 \mathrm{~Hz}, 2 \mathrm{H}), 5.88(\mathrm{bs}, 2 \mathrm{H}), 3.55(\mathrm{~s}, 3 \mathrm{H}) \mathrm{ppm} ;{ }^{13} \mathrm{C}-\mathrm{NMR}\left(\mathrm{CDCl}_{3}+\mathrm{DMSO}_{6}\right) \delta 162.1,161.0,157.3$, $149.8,136.4,127.9,122.7,122.1,113.1,54.7$ ppm; HRMS (ESI) Calc $\mathrm{C}_{14} \mathrm{H}_{14} \mathrm{~N}_{3} \mathrm{O}_{3}[\mathrm{M}+\mathrm{H}]^{+}$272.1030; found 272.1032 .

(Z)-N'-(Isonicotinoyloxy)-4-nitrobenzimidamide (10). Solvent: THF; R.T.: $7 \mathrm{~h}$; amine: $\mathrm{Et}_{3} \mathrm{~N}$; yellow crystals, yield $85 \%$, mp $176.2^{\circ} \mathrm{C}$ (ethyl acetate); IR (KBr): 3536, 3420, 3120, 1730, $1649 \mathrm{~cm}^{-1}$; ${ }^{1} \mathrm{H}-\mathrm{NMR}$ $\left(\mathrm{CDCl}_{3}+\mathrm{DMSO}_{-} d_{6}\right) \delta 8.72(\mathrm{~d}, J=5.9 \mathrm{~Hz}, 2 \mathrm{H}), 8.19(\mathrm{~d}, J=8.9 \mathrm{~Hz}, 2 \mathrm{H}), 8.00(\mathrm{~d}, J=8.9 \mathrm{~Hz}, 2 \mathrm{H}), 7.99(\mathrm{~d}$, $J=5.8 \mathrm{~Hz}, 2 \mathrm{H}), 6.90(\mathrm{br} \mathrm{s}, 2 \mathrm{H}) \mathrm{ppm} ;{ }^{13} \mathrm{C}-\mathrm{NMR}\left(\mathrm{CDCl}_{3}+\mathrm{DMSO}^{-} d_{6}\right) \delta 161.4,155.0,149.2,147.8,136.6$, 135.5, 127.3, 122.1, 121.8 ppm; HRMS (ESI) Calc $\mathrm{C}_{13} \mathrm{H}_{11} \mathrm{~N}_{4} \mathrm{O}_{4}[\mathrm{M}+\mathrm{H}]^{+}$287.0775; found 287.0773.

(E)-1-(Pyridin-4-yl)ethan-1-one O-(4-nitrobenzoyl) oxime (11). Prepared according to reference [32]. ${ }^{1} \mathrm{H}-\mathrm{NMR}\left(\mathrm{CDCl}_{3}\right) \delta 8.75(\mathrm{~d}, J=5.8 \mathrm{~Hz}, 2 \mathrm{H}), 8.37(\mathrm{~d}, J=8.7 \mathrm{~Hz}, 2 \mathrm{H}), 8.30(\mathrm{~d}, J=8.7 \mathrm{~Hz}, 2 \mathrm{H}), 7.70(\mathrm{~d}$, $J=5.8 \mathrm{~Hz}, 2 \mathrm{H}), 2.55(\mathrm{~s}, 3 \mathrm{H}) \mathrm{ppm}$.

(E)-1-(Pyridin-4-yl)ethan-1-one O-isonicotinoyl oxime (12). Solvent: THF; R.T.: 24 h; amine: DIPEA; white crystals, yield $89 \%$, mp $162.8^{\circ} \mathrm{C}$ (ethyl acetate); IR (KBr): $1753,1618 \mathrm{~cm}^{-1} ;{ }^{1} \mathrm{H}-\mathrm{NMR}\left(500 \mathrm{MHz}, \mathrm{CDCl}_{3}\right)$ $\delta 8.83(\mathrm{dd}, J=4.7,1.2 \mathrm{~Hz}, 2 \mathrm{H}), 8.71(\mathrm{dd}, J=4.7,1.2 \mathrm{~Hz}, 2 \mathrm{H}), 7.91(\mathrm{dd}, J=4.7,1.4 \mathrm{~Hz}, 2 \mathrm{H}), 7.67$ (dd, $J=4.7,1.4 \mathrm{~Hz}, 2 \mathrm{H}), 2.52$ (s, 3H) ppm; ${ }^{13} \mathrm{C}-\mathrm{NMR}\left(125 \mathrm{MHz}, \mathrm{CDCl}_{3}\right) \delta 162.4,161.9,150.8,150.4,141.7$, 135.9, 122.7, 121.0, 14.2 ppm; HRMS (ESI) Calc $\mathrm{C}_{13} \mathrm{H}_{12} \mathrm{~N}_{3} \mathrm{O}_{2}[\mathrm{M}+\mathrm{H}]^{+}$242.0924; found 242.0922.

(E)-Picolinaldehyde O-4-nitrobenzoyl oxime (13). Prepared according to reference [30]. ${ }^{1} \mathrm{H}-\mathrm{NMR}\left(\mathrm{CDCl}_{3}\right)$ $\delta 8.71(\mathrm{~d}, J=4.3 \mathrm{~Hz}, 1 \mathrm{H}), 8.67(\mathrm{~s}, 1 \mathrm{H}), 8.35(\mathrm{~d}, J=8.9 \mathrm{~Hz}, 2 \mathrm{H}), 8.31(\mathrm{~d}, J=8.9 \mathrm{~Hz}, 2 \mathrm{H}), 8.18(\mathrm{~d}, J=7.9 \mathrm{~Hz}$, $1 \mathrm{H}), 7.82(\mathrm{dt}, J=7.8,1.3 \mathrm{~Hz}, 1 \mathrm{H}), 7.42(\mathrm{dd}, J=6.6,4.9 \mathrm{~Hz}, 1 \mathrm{H}) \mathrm{ppm}$.

(E)-Nicotinaldehyde O-4-nitrobenzoyl oxime (14). Prepared according to reference [30]. ${ }^{1} \mathrm{H}-\mathrm{NMR}$ $\left(\right.$ DMSO- $\left._{6}\right) \delta 9.07(\mathrm{~s}, 1 \mathrm{H}), 8.95(\mathrm{~d}, J=1.6 \mathrm{~Hz}, 1 \mathrm{H}), 8.76(\mathrm{dd}, J=4.8,1.6 \mathrm{~Hz}, 1 \mathrm{H}), 8.42(\mathrm{dd}, J=8.9$, $1.8 \mathrm{~Hz}, 2 \mathrm{H}), 8.31(\mathrm{dd}, J=8.9,1.8 \mathrm{~Hz}, 2 \mathrm{H}), 8.24(\mathrm{dt}, J=8.0,1.8 \mathrm{~Hz}, 1 \mathrm{H}), 7.58(\mathrm{dd}, J=7.9,4.9 \mathrm{~Hz}, 1 \mathrm{H}) \mathrm{ppm}$.

(E)-Isonicotinaldehyde O-4-nitrobenzoyl oxime (15). Prepared according to reference [30]. ${ }^{1} \mathrm{H}-\mathrm{NMR}$ $\left(\right.$ DMSO- $\left.d_{6}\right) \delta 9.03(\mathrm{~s}, 1 \mathrm{H}), 8.76(\mathrm{~d}, J=5.1 \mathrm{~Hz}, 2 \mathrm{H}), 8.41(\mathrm{~d}, J=8.5 \mathrm{~Hz}, 2 \mathrm{H}), 8.29(\mathrm{~d}, J=8.5 \mathrm{~Hz}, 2 \mathrm{H}), 7.75$ $(\mathrm{d}, J=5.1 \mathrm{~Hz}, 2 \mathrm{H}) \mathrm{ppm}$. 
(E)-4-Methoxybenzaldehyde O-(4-nitrobenzoyl) oxime (16), ref mp $171^{\circ} \mathrm{C}$ [75]. Solvent: THF; R.T.: 12 h; amine: $\mathrm{Et}_{3} \mathrm{~N}$; light brown crystals, yield $78 \%, \mathrm{mp} 169-171^{\circ} \mathrm{C}$ (ethyl acetate/ethanol); IR (KBr): 1754, $\left.1599 \mathrm{~cm}^{-1} ;{ }^{1} \mathrm{H}-\mathrm{NMR}\left(\mathrm{CDCl}_{3}+\mathrm{DMSO}_{-}\right)_{6}\right) \delta .34(\mathrm{~s}, 1 \mathrm{H}), 8.12(\mathrm{~d}, J=9.0 \mathrm{~Hz}, 2 \mathrm{H}), 8.08(\mathrm{~d}, J=9.0 \mathrm{~Hz}, 2 \mathrm{H})$, $7.53(\mathrm{~d}, J=8.8 \mathrm{~Hz}, 2 \mathrm{H}), 6.76(\mathrm{~d}, J=8.8 \mathrm{~Hz}, 2 \mathrm{H}), 3.65(\mathrm{~s}, 3 \mathrm{H}) \mathrm{ppm} ;{ }^{13} \mathrm{C}-\mathrm{NMR}\left(\mathrm{CDCl}_{3}+\mathrm{DMSO}-d_{6}\right) \delta 162.1$, 161.6, 156.7, 150.0, 133.7, 130.2, 129.8, 123.1, 121.4, 113.9, 54.9 ppm; HRMS (ESI) Calc $\mathrm{C}_{15} \mathrm{H}_{13} \mathrm{~N}_{2} \mathrm{O}_{5}$ $[\mathrm{M}+\mathrm{H}]^{+}$301.0819; found 301.0810.

(E)-Picolinaldehyde O-isonicotinoyl oxime (17). Solvent: THF; R.T.: 24 h; amine: DIPEA; beige crystals, yield $85 \%$, mp $154{ }^{\circ} \mathrm{C}$ (hexanes/ethyl acetate); IR (KBr): 1754, $1612 \mathrm{~cm}^{-1},{ }^{1} \mathrm{H}-\mathrm{NMR}\left(\mathrm{CDCl}_{3}\right) \delta 8.84(\mathrm{~d}$, $J=5.7 \mathrm{~Hz}, 2 \mathrm{H}), 8.69(\mathrm{~d}, J=4.3 \mathrm{~Hz}, 1 \mathrm{H}), 8.64(\mathrm{~s}, 1 \mathrm{H}), 8.16(\mathrm{~d}, J=7.9 \mathrm{~Hz}, 1 \mathrm{H}), 7.93(\mathrm{~d}, J=5.7 \mathrm{~Hz}, 2 \mathrm{H})$, $7.79(\mathrm{dd}, J=7.4,6.9 \mathrm{~Hz}, 1 \mathrm{H}), 7.39(\mathrm{dd}, J=6.7,5.11 \mathrm{H}) \mathrm{ppm} ;{ }^{13} \mathrm{C}-\mathrm{NMR}\left(\mathrm{CDCl}_{3}\right) \delta 162.3,158.2,150.8$, 150.0, 149.4, 136.8, 135.6, 125.8, 122.8, 122.3 ppm; HRMS (ESI) Calc $\mathrm{C}_{12} \mathrm{H}_{10} \mathrm{~N}_{3} \mathrm{O}_{2}[\mathrm{M}+\mathrm{H}]^{+} 228.0768$; found 228.0765 .

(E)-Nicotinaldehyde O-isonicotinoyl oxime (18). Solvent: THF; R.T.: 24h; amine: DIPEA; off white crystals, yield $82 \%$, mp $152{ }^{\circ} \mathrm{C}$ (ethyl acetate); IR (KBr): 1749, $1612 \mathrm{~cm}^{-1} ;{ }^{1} \mathrm{H}-\mathrm{NMR}\left(\mathrm{DMSO}-d_{6}\right) \delta 9.05(\mathrm{~s}, 1 \mathrm{H})$, $8.95(\mathrm{~s}, 1 \mathrm{H}), 8.88(\mathrm{~d}, J=5.4 \mathrm{~Hz}, 2 \mathrm{H}), 8.75(\mathrm{~d}, J=4.6 \mathrm{~Hz}, 1 \mathrm{H}), 8.24(\mathrm{~d}, J=7.9 \mathrm{~Hz}, 1 \mathrm{H}), 7.95(\mathrm{~d}, J=5.4 \mathrm{~Hz}$, 2H), $7.58(\mathrm{dd}, J=7.1,5.0 \mathrm{~Hz}, 1 \mathrm{H}) \mathrm{ppm} ;{ }^{13} \mathrm{C}-\mathrm{NMR}\left(\mathrm{DMSO}-d_{6}\right) \delta 162.0,156.7,152.7,151.0,149.7,135.3$, 134.9, 126.0, 124.3, 122.6 ppm; HRMS (ESI) Calc $\mathrm{C}_{12} \mathrm{H}_{10} \mathrm{~N}_{3} \mathrm{O}_{2}[\mathrm{M}+\mathrm{H}]^{+}$228.0768; found 228.0766.

(E)-Isonicotinaldehyde O-isonicotinoyl oxime (19). Solvent: THF; R.T.: 24 h; amine: DIPEA; beige crystals, yield $77 \%$, mp $138{ }^{\circ} \mathrm{C}$ (hexanes/ethyl acetate); IR (KBr): 1753, $1596 \mathrm{~cm}^{-1} ;{ }^{1} \mathrm{H}-\mathrm{NMR}\left(\mathrm{CDCl}_{3}\right) \delta 8.85(\mathrm{~d}$, $J=5.8 \mathrm{~Hz}, 2 \mathrm{H}), 8.76(\mathrm{~d}, J=5.7 \mathrm{~Hz}, 2 \mathrm{H}), 8.55(\mathrm{~s}, 1 \mathrm{H}), 7.92(\mathrm{~d}, J=5.8 \mathrm{~Hz}, 2 \mathrm{H}), 7.67(\mathrm{~d}, J=5.9 \mathrm{~Hz}, 2 \mathrm{H})$ ppm; ${ }^{13} \mathrm{C}-\mathrm{NMR}\left(\mathrm{CDCl}_{3}\right) \delta 162.0,155.6,150.8,150.8,137.0,135.4,122.8,121.9$ ppm; HRMS (ESI) Calc $\mathrm{C}_{12} \mathrm{H}_{10} \mathrm{~N}_{3} \mathrm{O}_{2}[\mathrm{M}+\mathrm{H}]^{+}$228.0768; found 228.0764.

(E)-4-Methoxybenzaldehyde O-isonicotinoyl oxime (20). Solvent: $\mathrm{CHCl}_{3}$; R.T.: 4 h; amine: $\mathrm{Et}_{3} \mathrm{~N}$; column chromatography (hexanes/ethyl acetate); beige crystals, yield $83 \%, \mathrm{mp} 141{ }^{\circ} \mathrm{C}$ (hexanes/ethyl acetate); IR (KBr): 1743, $1605 \mathrm{~cm}^{-1},{ }^{1} \mathrm{H}-\mathrm{NMR}\left(\mathrm{CDCl}_{3}\right) \delta 8.81(\mathrm{dd}, J=4.5,1.5 \mathrm{~Hz}, 2 \mathrm{H}), 8.48(\mathrm{~s}, 1 \mathrm{H}), 7.90(\mathrm{dd}$, $J=4.5,1.5 \mathrm{~Hz}, 2 \mathrm{H}), 7.73(\mathrm{~d}, J=8.8 \mathrm{~Hz}, 2 \mathrm{H}), 6.95(\mathrm{~d}, J=8.8 \mathrm{~Hz}, 2 \mathrm{H}), 3.85(\mathrm{~s}, 3 \mathrm{H}) \mathrm{ppm} ;{ }^{13} \mathrm{C}-\mathrm{NMR}\left(\mathrm{CDCl}_{3}\right)$ $\delta$ 162.7, 162.6, 157.1, 150.7, 136.1, 130.4, 122.8, 122.0, 114.5, 55.4 ppm; HRMS (ESI) Calc $\mathrm{C}_{14} \mathrm{H}_{13} \mathrm{~N}_{2} \mathrm{O}_{3}$ $[\mathrm{M}+\mathrm{H}]^{+}$257.0921; found 257.0920.

(E)-4-Nitrobenzaldehyde O-isonicotinoyl oxime (21). Solvent: $\mathrm{CHCl}_{3}$; R.T.: 4 h; amine: Et 3 N; yellow crystals, yield $79 \%, \mathrm{mp} 164{ }^{\circ} \mathrm{C}$ (hexanes/ethyl acetate); IR (KBr): 1757, $1594 \mathrm{~cm}^{-1} ;{ }^{1} \mathrm{H}-\mathrm{NMR}\left(\mathrm{CDCl}_{3}\right) \delta$ $8.86(\mathrm{~d}, J=5.7 \mathrm{~Hz}, 2 \mathrm{H}), 8.67(\mathrm{~s}, 1 \mathrm{H}), 8.33(\mathrm{~d}, J=8.7 \mathrm{~Hz}, 2 \mathrm{H}), 8.01(\mathrm{~d}, J=8.7 \mathrm{~Hz}, 2 \mathrm{H}), 7.94(\mathrm{~d}, J=5.7 \mathrm{~Hz}$, 2H) ppm; ${ }^{13} \mathrm{C}-\mathrm{NMR}\left(\mathrm{CDCl}_{3}\right) \delta 162.1,155.2,150.9,149.8,135.6,135.4,129.4,124.2,122.8$ ppm; HRMS (ESI) Calc $\mathrm{C}_{13} \mathrm{H}_{10} \mathrm{~N}_{3} \mathrm{O}_{4}[\mathrm{M}+\mathrm{H}]^{+}$272.0666; found 272.0663 .

\subsection{DNA Photo-Cleavage Experiments}

\subsubsection{Cleavage of Supercoiled Circular pBluescript KS II DNA and pBR322}

The reaction mixtures $(20 \mu \mathrm{L})$ containing supercoiled circular pBluescipt KS II DNA stock solution (Form I, $50 \mu \mathrm{M}$ /base pair, $500 \mathrm{ng}$ ), compounds, and Tris buffer ( $25 \mu \mathrm{M}, \mathrm{pH}$ 6.8) in Pyrex vials were incubated for $30 \mathrm{~min}$ at $37^{\circ} \mathrm{C}$, centrifuged, and then irradiated with UV light $(312 \mathrm{~nm}, 90 \mathrm{~W})$ under aerobic conditions at room temperature for $15 \mathrm{~min}$. For the case of pBR322 plasmid DNA, the above mentioned procedure has been followed. After centrifugion, the samples were irradiated with UVA light $(365 \mathrm{~nm}, 18 \mathrm{~W})$ under aerobic conditions at room temperature for $120 \mathrm{~min}$. After addition of the gel-loading buffer (6X Orange DNA Loading Dye $10 \mathrm{mM}$ Tris- $\mathrm{HCl}$ (pH 7.6), 0.15\% orange G, $0.03 \%$ xylene cyanol FF, $60 \%$ glycerol, and 60 mM EDTA, by Fermentas), the reaction mixtures were loaded on a $1 \%$ agarose gel with EB staining. The electrophoresis tank was attached to a power supply at a constant current ( $65 \mathrm{~V}$ for $1 \mathrm{~h})$. The gel was visualized by $312 \mathrm{~nm} \mathrm{UV}$ transilluminator and photographed by an FB-PBC-34 camera vilber lourmat. Quantitation of DNA-cleaving activities 
was performed by integration of the optical density as a function of the band area using the program “Image J" version 1.50.I [76].

\subsubsection{Calculation of Single-Strand Damage (ss)\% and Double-Strand Damage (ds)\%}

ss $\%$ and ds \% damages were calculated according to the following Equations (1) and (2):

$$
\begin{aligned}
& \mathrm{ss} \%=\frac{\text { Form II }}{\text { Form I }+ \text { Form II }+ \text { Form III }} \times 100 \\
& \mathrm{ds} \%=\frac{\text { Form III }}{\text { Form I }+ \text { Form II }+ \text { Form III }} \times 100
\end{aligned}
$$

As Form II we consider Form II of each series minus Form II of the irradiated control DNA. As Form I we consider Form I of each series. The amount of supercoiled DNA was multiplied by factor of 1.43 to account for reduced ethidium bromide intercalation into supercoiled DNA.

\subsection{Calculation of the N-O Bond Dissociation Energies}

All ground state calculation were carried out using the unrestricted B3PW91/6-31g(d) method without any symmetry constraint. The optimized structures were characterized as minima by frequency calculation at the same level of theory. Bond dissociation energies $\left(\mathrm{D}_{0}\right)$ calculated according the general equation: $\mathrm{D}_{0}=\mathrm{E}_{0}($ radical1 $)+\mathrm{E}_{0}\left(\right.$ radical2) $-\mathrm{E}_{0}$ (molecule), where $\mathrm{E}_{0}$ is the calculated electronic energy corrected with zero point vibrational energy (ZPE) [77].

\subsection{Interaction with CT DNA}

In order to evaluate the biological behavior of selected compounds $(\mathbf{1 - 3}, \mathbf{5}, \mathbf{8 - 1 5}, \mathbf{1 9}$ and 21) with CT DNA, the compounds were initially dissolved in DMSO (1 mM). Mixing of such solutions with the aqueous buffer DNA solutions used in the studies never exceeded 5\% DMSO $(v / v)$ in the final solution. All studies were performed at room temperature. Control experiments with DMSO were performed and no changes in the spectra were observed.

\subsubsection{Study with UV Spectroscopy}

The interaction of compounds 1-16, 19 and 21 with CT DNA was studied by UV spectroscopy as a means to investigate the possible binding modes to CT DNA and to calculate the binding constants to CT DNA $\left(\mathrm{K}_{\mathrm{b}}\right)$. The UV spectra of a CT DNA solution $(0.14-0.16 \mathrm{mM})$ were recorded in the presence of the compounds at diverse [compound]/[DNA] mixing ratios $(=r)$ as well as the UV spectra of the compounds $(10-100 \mu \mathrm{M})$ in the presence of increasing amounts of CT DNA $\left(r^{\prime}=1 / r=[D N A] /[\right.$ compound] mixing ratios). Control experiments with DMSO were performed and no changes in the spectra of CT DNA were observed.

The $\mathrm{K}_{\mathrm{b}}$ constants (in $\mathrm{M}^{-1}$ ) were obtained by monitoring the absorbance changes at the corresponding $\lambda_{\max }$ with increasing concentrations of CT DNA and were calculated by the ratio of slope to the $y$ intercept in plots [DNA] $/\left(\varepsilon_{\mathrm{A}}-\varepsilon_{\mathrm{f}}\right)$ versus [DNA], according to the Wolfe-Shimer equation [65]:

$$
\frac{[\mathrm{DNA}]}{\left(\varepsilon_{\mathrm{A}}-\varepsilon_{\mathrm{f}}\right)}=\frac{[\mathrm{DNA}]}{\left(\varepsilon_{\mathrm{b}}-\varepsilon_{\mathrm{f}}\right)}+\frac{1}{\mathrm{~K}_{\mathrm{b}}\left(\varepsilon_{\mathrm{b}}-\varepsilon_{\mathrm{f}}\right)}
$$

where [DNA] $=$ is the concentration of CT DNA in base pairs, $\varepsilon_{\mathrm{A}}=\mathrm{A}_{\mathrm{obsd}} /$ [compound], $\varepsilon_{\mathrm{f}}=$ the extinction coefficient for the free compound and $\varepsilon_{b}=$ the extinction coefficient for the compound in the fully bound form.

\subsubsection{Viscometry}

The viscosity of CT DNA ([DNA] $=0.1 \mathrm{mM})$ in buffer solution $(150 \mathrm{mM} \mathrm{NaCl}$ and $15 \mathrm{mM}$ trisodium citrate at $\mathrm{pH}$ 7.0) was measured in the presence of increasing amounts of the compounds 
(up to the value of $r=0.35$ ). All measurements were performed at room temperature. The obtained data are presented as $\left(\eta / \eta_{0}\right)^{1 / 3}$ versus $r$, where $\eta$ is the viscosity of CT DNA in the presence of the compound, and $\eta_{0}$ is the viscosity of DNA alone in buffer solution.

\subsubsection{Competitive Studies with EB}

The competitive studies of each compound with EB were investigated with fluorescence emission spectroscopy in order to examine the potential of the compound to displace EB from its DNA-EB conjugate. The DNA-EB conjugate was prepared by the pre-treatment of $20 \mu \mathrm{M}$ EB with $26 \mu \mathrm{M}$ CT DNA in buffer $(150 \mathrm{mM} \mathrm{NaCl}$ and $15 \mathrm{mM}$ trisodium citrate at $\mathrm{pH} 7.0)$ for $1 \mathrm{~h}$. The possible intercalating effect of the compounds was monitored by recording the variation of fluorescence emission spectra (excitation wavelength at $540 \mathrm{~nm}$ ) of the DNA-EB system upon stepwise addition of a solution of the compound.

The Stern-Volmer constant $\left(\mathrm{K}_{\mathrm{SV}}\right.$, in $\left.\mathrm{M}^{-1}\right)$ is used to evaluate the quenching efficiency for each compound according to the Stern-Volmer equation [69]:

$$
\frac{I o}{I}=1+k_{q} \tau_{0}[Q]=1+K_{S V}[Q]
$$

where Io and I are the emission intensities in the absence and the presence of the quencher (i.e., compounds 1-16, 19 and 21, respectively), [Q] is the concentration of the quencher, $\tau_{\mathrm{o}}=$ the average lifetime of the emitting system without the quencher and $\mathrm{k}_{\mathrm{q}}=$ the quenching constant. $\mathrm{K}_{\mathrm{SV}}$ was obtained from the Stern-Volmer plots by the slope of the diagram Io/I versus [Q]. Taking $\tau_{\mathrm{o}}=23 \mathrm{~ns}$ as the fluorescence lifetime of the EB-DNA system [72], the quenching constants $\left(\mathrm{k}_{\mathrm{q}}\right.$, in $\left.^{-1} \mathrm{~s}^{-1}\right)$ of the compounds was determined.

\section{Conclusions}

Oxime esters are easily accessible on a large scale and can be stored for prolonged periods of time. Aldoxime, ketoxime and amidoxime esters bearing the pyridine and $p$-nitrophenyl moieties as both oxime substituents and/or ester conjugates were examined as DNA photocleavers. Both moieties were found to be important for the activity. Those compounds exhibited good to excellent binding to DNA and efficient DNA photocleavage, at $312 \mathrm{~nm}$ at a concentration of $100 \mu \mathrm{M}(\mathbf{1}-\mathbf{3}, \mathbf{5}, \mathbf{1 0}, \mathbf{1 1}-\mathbf{1 5}$, 17, 19 and 21). Some selected compounds were able to photocleave DNA at $365 \mathrm{~nm}(\mathbf{1}-\mathbf{3}, 5,10$ at a concentration of $500 \mu \mathrm{M})$. Their mode of action seems to follow the N-O bond homolytic cleavage with the generation of active $p$-nitrobenzoyl or $p$-pyridine carbonyloxyl radicals which attack DNA. Since however, DNA photo-cleavage is a rather complicated phenomenon, some observed differences could be attributed to other factors such as the presence of oxygen (which may produce reactive oxygen species), the mode of DNA affinity or the existence of specific structures facilitating $\mathrm{H}$-abstraction. In general, for compounds with comparable structures, it seems that the lower the BDE the higher the $\%$ DNA photocleavage. Compounds 4, 9 and 16, as well as 6-8, although they possessed adequate to sufficient DNA binding activities, were found to lack DNA photocleavage activity, at the studied conditions. Nevertheless, their affinity to DNA may also lead to other cancer therapeutic approaches than photocleavage. Thus, the studied oxime esters emerge as lead compounds for the investigation of cancer therapeutics, in general, and in the field of photo-chemotherapy and photo-dynamic therapy, in particular.

Supplementary Materials: The following are available online at www.mdpi.com/1420-3049/21/7/864/s1. Supplementary Information contains UV absorption spectra, UV spectra of representative compounds in the presence of CT DNA, plots of $\frac{[D N A]}{\left(\varepsilon_{A}-\varepsilon_{f}\right)}$ versus [DNA], EB-DNA fluorescence emission spectra in the presence of compound 1, and Stern-Volmer quenching plot of EB-DNA fluorescence for the compounds. 
Acknowledgments: We are obliged to the editors who totally waived the publishing fees for the manuscript. We thank Assoc. A. K. Zarkadis (Univ. of Ioannina, Chemistry Department) for access to Gaussian 09, Revision B.01 program for support on the calculation of the $\mathrm{N}-\mathrm{O}$ bond energies of the compounds. We are thankful to the ProFI (Proteomics Facility at IMBB-FORTH) for performing all the HRMS analyses.

Author Contributions: M.P. and N.-P.A. performed chemical synthesis and DNA photo-cleavage experiments; P.S.G. performed DNA photo-cleavage experiments and calculations of N-O bond energies; M.K. contributed reagents, materials and consulting for biology; A.E.K. contributed to NMR spectrometry, analyzed data and consulted overall; K.D. performed the DNA affinity experiments; G.P. supervised the DNA affinity experiments and wrote the corresponding part of the manuscript; K.C.F. conceived and designed the whole project, contributed reagents and materials, supervised the chemical synthesis and DNA photo-cleavage experiments and prepared the manuscript.

Conflicts of Interest: The authors declare no conflict of interest.

\section{Abbreviations}

The following abbreviations are used in this manuscript:

$\begin{array}{ll}\text { CT } & \text { calf-thymus } \\ \text { EB } & \text { ethidium bromide } \\ \text { BDE } & \text { Bond Dissociation Energy } \\ \text { THF } & \text { tetrahydrofuran } \\ \text { DMF } & \text { Dimethyl formamide } \\ \text { DMSO } & \text { Dimethyl sulfoxide } \\ \text { DIPEA } & \text { Diisopropyl ethyl amine }\end{array}$

\section{References}

1. Dabrowski, J.M.; Arnaut, L.G. Photodynamic Therapy (PDT) of Cancer: From a Local to a Systemic Treatment. Photochem. Photobiol. Sci. 2015, 14, 1765-1780.

2. Lucky, S.S.; Soo, K.C.; Zhang, Y. Nanoparticles in Photodynamic Therapy. Chem. Rev. 2015, 115, $1990-2042$. [CrossRef] [PubMed]

3. Weijer, R.; Broekgaarden, M.; Kos, M.; van Vught, R.; Rauws, E.A.J.; Breukink, E.; van Gulik, T.M.; Storm, G.; Heger, M. Enhancing photodynamic therapy of refractory solid cancers: Combining second-generation photosensitizers with multi-targeted liposomal delivery. J. Photochem. Photobiol. C 2015, 23, 103-131. [CrossRef]

4. Yano, S.; Hirohara, S.; Obata, M.; Yuichiro Hagiya, Y.; Ogura, S.I.; Ikeda, A.; Kataoka, H.; Tanaka, M.; Joh, T. Current states and future views in photodynamic therapy. J. Photochem. Photobiol. C 2011, 12, 46-67. [CrossRef]

5. Bechet, D.; Mordon, S.R.; Guillemin, F.; Barberi-Heyob, M.A. Photodynamic therapy of malignant brain tumours: A complementary approach to conventional therapies. Cancer Treat. Rev. 2014, 40, 229-241. [CrossRef] [PubMed]

6. Sirajuddin, M.; Ali, S.; Badshah, A. Drug-DNA interactions and their study by UV-Visible, fluorescence spectroscopies and cyclic voltammetry. J. Photochem. Photobiol. B: Biol. 2013, 124, 1-19. [CrossRef] [PubMed]

7. Ananya, P.; Santanu, B. Chemistry and biology of DNA-binding small molecules. Curr. Sci. 2012, 102, 212-231.

8. Abrahamse, H.; Hamblin, M.R. New photosensitizers for photodynamic therapy. Biochem. J. 2016, 473, 347-364. [CrossRef] [PubMed]

9. Reelfs, O.; Karran, P.; Young, A.R. 4-thiothymidine sensitization of DNA to UVA offers potential for a novel Photochemotherapy. Photochem. Photobiol. Sci. 2012, 11, 148-154. [CrossRef] [PubMed]

10. Vittara, N.B.R.; Cominib, L.; Fernadeza, I.M.; Agostinia, E.; Nuñez-Montoyab, S.; Cabrerab, J.L.; Rivarola, V.A. Photochemotherapy using natural anthraquinones: Rubiadin and Soranjidiol sensitize human cancer cell to die by apoptosis. Photodiagnosis. Photodyn. Ther. 2014, 11, 182-192. [CrossRef] [PubMed]

11. Armitage, B. Photocleavage of Nucleic Acids. Chem. Rev. 1998, 98, 1171-1200. [CrossRef] [PubMed]

12. Kar, M.; Basak, A. Design, Synthesis, and Biological Activity of Unnatural Enediynes and Related Analogues Equipped with pH-Dependent or Phototriggering Devices. Chem. Rev. 2007, 107, 2861-2890. [CrossRef] [PubMed] 
13. Breiner, B.; Kaya, K.; Roy, S.; Yang, W.-Y.; Alabugin, I.V. Hybrids of amino acids and acetylenic DNA-photocleavers: Optimizing efficiency and selectivity for cancer phototherapy. Org. Biomol. Chem. 2012, 10, 3974-3987. [CrossRef] [PubMed]

14. Rajendran, M. Quinones as photosensitizer for photodynamic therapy: ROS generation, mechanism and detection methods. Photodiagnosis Photodyn. Ther. 2016, 13, 175-187. [CrossRef] [PubMed]

15. Watson, J.D.; Baker, T.A.; Bell, S.P.; Gann, A.; Levine, M.; Losick, R. Molecular Biology of the Gene, 5th ed.; Cold Spring Harbor Laboratory Press: Plainview, NY, USA, 2004; Chapters 9 and 10.

16. Elmroth, K.; Nygren, J.; Mårtensson, S.; Ismail, I.H.; Hammarsten, O. Cleavage of cellular DNA by calicheamicin $\gamma 1$. DNA Repair 2003, 2, 363-374. [CrossRef]

17. Kaya, K.; Johnson, M.; Alabugin, I.V. Opening Enediyne Scissors Wider: pH-Dependent DNA Photocleavage by meta-Diyne Lysine Conjugates. Photochem. Photobiol. 2015, 91, 748-758. [CrossRef] [PubMed]

18. Abele, E.; Abele, R. Recent Advances in the Synthesis of Heterocycles from Oximes. Curr. Org. Synth. 2014, 11, 403-428. [CrossRef]

19. O'Brien, C. The Rearrangement of Ketoxime O-Sulfonates to Amino Ketones (The Neber Rearrangement). Chem. Rev. 1964, 64, 81-89. [CrossRef]

20. Ooi, T.; Takahashi, M.; Doda, K.; Maruoka, K. Asymmetric Induction in the Neber Rearrangement of Simple Ketoxime Sulfonates under Phase-Transfer Conditions: Experimental Evidence for the Participation of an Anionic Pathway. J. Am. Chem. Soc. 2002, 124, 7640-7641. [CrossRef] [PubMed]

21. Tian, B.-X.; An, N.; Deng, W.-P.; Eriksson, L.A. Catalysts or Initiators? Beckmann Rearrangement Revisited. J. Org. Chem. 2013, 78, 6782-6785. [CrossRef] [PubMed]

22. Nicolaides, D.N.; Varella, E.A. The Chemistry of Acid Derivatives; The Chemistry of Amidoximes; Patai, S., Ed.; Interscience: New York, NY, USA, 1992; Suppl. B, Volume 2, Part 2; pp. 875-966.

23. Fylaktakidou, K.C.; Hadjipavlou-Litina, D.J.; Litinas, K.E.; Varella, E.; Nicolaides, D.N. Recent Developments in the Chemistry and in the Biological Applications of Amidoximes. Curr. Pharm. Des. 2008, 14, 1001-1047. [CrossRef] [PubMed]

24. Chowdhury, N.; Dutta, S.; Dasgupta, S.; Pradeep Singh, N.D.; Baidya, M.; Ghosh, S.K. Synthesis, photophysical, photochemical, DNA cleavage/binding and cytotoxic properties of pyrene oxime ester conjugates. Photochem. Photobiol. Sci. 2012, 11, 1239-1250. [CrossRef] [PubMed]

25. Hwu, J.R.; Tsay, S.-C.; Hong, S.C.; Leu, Y.-J.; Liu, C.-F.; Chou, S.-S.P. Oxime esters of anthraquinone as photo-induced DNA-cleaving agents for single- and double-strand scissions. Tetrahedron Lett. 2003, 44, 2957-2960. [CrossRef]

26. Hwu, J.R.; Tsay, S.-C.; Hong, S.C.; Hsu, M.-H.; Liu, C.-F.; Chou, S.-S.P. Relationship Between Structure of Conjugated Oxime Esters and Their Ability to Cleave DNA. Bioconjug. Chem. 2013, 24, 1778-1783. [CrossRef] [PubMed]

27. Bindu, P.J.; Mahadevan, K.M.; Satyanarayan, N.D.; Ravikumar Naik, T.R. Synthesis and DNA cleavage studies of novel quinoline oxime esters. Bioorg. Med. Chem. 2012, 22, 898-900. [CrossRef] [PubMed]

28. Hwu, J.R.; Yang, J.-R.; Tsay, S.-C.; Hsu, M.-H.; Chen, Y.-C.; Chou, S.-S.P. Photo-Induced DNA cleavage by (heterocyclo)carbonyl oxime esters of anthraquinone. Tetrahedron Lett. 2008, 49, 3312-3315. [CrossRef]

29. Chou, S.-S.P.; Juan, J.-C.; Tsay, S.-C.; Huang, K.P.; Hwu, J.R. Oxime Esters of 2,6-Diazaanthracene-9,10-dione and 4,5-Diazafluoren-9-one as Photo-induced DNA-Cleaving Agents. Molecules 2012, 17, 3370-3382. [CrossRef] [PubMed]

30. Karamtzioti, P.; Papastergiou, A.; Stefanakis, J.G.; Koumbis, A.E.; Anastasiou, I.; Koffa, M.; Fylaktakidou, K.C. $\mathrm{O}$-Benzoyl pyridine aldoxime and amidoxime derivatives: Novel efficient DNA photo-cleavage agents. Med. Chem. Commun. 2015, 6, 719-726. [CrossRef]

31. Theodorakis, E.A.; Xiang, X.; Lee, M.; Gibson, T. On the Mechanism of Photo-induced Nucleic Acid Cleavage Using N-Aroyloxy-2-thiopyridones. Tetrahedron Lett. 1998, 39, 3383-3386. [CrossRef]

32. Theodorakis, E.A.; Wilcoxen, K.M. N-Aroyloxy-2-thiopyridones as efficient oxygen-radical generators: Novel time-controlled DNA photocleaving reagents. Chem. Commun. 1996, 1927-1928. [CrossRef]

33. Blom, P.; Xiang, X.; Kao, D.; Theodorakis, E.A. Design, Synthesis, and Evaluation of N-Aroyloxy-2-thiopyridones as DNA Photocleaving Reagents. Bioorg. Med. Chem. 1999, 7, 727-736. [CrossRef] 
34. Andreou, N.-P.; Dafnopoulos, K.; Tortopidis, C.; Koumbis, A.E.; Koffa, M.; Psomas, G.; Fylaktakidou, K.C. Alkyl and Aryl Sulfonyl p-Pyridine Ethanone Oximes are Efficient DNA Photo-cleavage Agents. J. Photochem. Photobiol. B Biol. 2016, 158, 30-38. [CrossRef] [PubMed]

35. Papastergiou, A.; Perontsis, S.; Gritzapis, P.; Koumbis, A.E.; Koffa, M.; Psomas, G.; Fylaktakidou, K.C. Evaluation of O-Alkyl and Aryl Sulfonyl Aromatic and Heteroaromatic Amidoximes as Novel Potent DNA Photo-Cleavers. Photochem. Photobiol. Sci. 2016, 15, 351-360. [CrossRef] [PubMed]

36. Fernandes, L.; Fischer, F.L.; Ribeiro, C.W.; Silveira, G.P.; Sá, M.M.; Nomeb, F.; Terenzi, H. Metal-Free artificial nucleases based on simple oxime and hydroxylamine scaffolds. Bioorg. Med. Chem. Lett. 2008, 18, 4499-4502. [CrossRef] [PubMed]

37. Abele, E.; Abele, R.; Lukevics, E. Pyridine Oximes: Synthesis, Reactions, and Biological Activity. (Review). Chem. Heterocycl. Compd. 2003, 39, 825-865. [CrossRef]

38. Kliachyna, M.; Santoni, G.; Nussbaum, V.; Renou, J.; Sanson, B.; Colletier, J.-P.; Arboléas, M.; Loiodice, M.; Weik, M.; Jean, L.; et al. Design, synthesis and biological evaluation of novel tetrahydroacridine pyridinealdoxime and -amidoxime hybrids as efficient uncharged reactivators of nerve agent-inhibited human acetylcholinesterase. Eur. J. Med. Chem. 2014, 78, 455-467. [CrossRef] [PubMed]

39. Mercey, G.; Renou, J.; Verdelet, T.; Kliachyna, M.; Baati, R.; Gillon, E.; Arboléas, M.; Loiodice, M.; Nachon, F.; Jean, L.; et al. Phenyltetrahydroisoquinoline-Pyridinaldoxime Conjugates as Efficient Uncharged Reactivators for the Dephosphylation of Inhibited Human Acetylcholinesterase. J. Med. Chem. 2012, 55, 10791-10795. [CrossRef] [PubMed]

40. Renou, J.; Loiodice, M.; Arboléas, M.; Baati, R.; Jean, L.; Nachon, F.; Renard, P.-Y. Tryptoline-3-hydroxypyridinaldoxime conjugates as efficient reactivators of phosphylated human acetyl and butyrylcholinesterases. Chem. Commun. 2014, 50, 3947-3950. [CrossRef] [PubMed]

41. Nicolaides, D.N.; Fylaktakidou, K.C.; Litinas, K.E.; Papageorgiou, G.K.; Hadjipavlou-Litina, D. 1,3-Cycloaddition Reactions of 2-oxo-2H-[1]benzopyran-4-carbonitrile N-oxide. Synthesis of Several New 4-Substituted Coumarins. J. Heterocyclic Chem. 1998, 35, 619-625. [CrossRef]

42. Nicolaides, D.N.; Gautam, D.R.; Litinas, K.E.; Manouras, C.; Fylaktakidou, K.C. Reactions of 2-(Methoxyimino)benzene-1-ones with a-Alkyl-ethoxycarbonyl-methylene(triphenyl) phosphoranes. Tetrahedron 2001, 57, 9469-9474. [CrossRef]

43. Gautam, D.D.R.; Protopapas, J.; Fylaktakidou, K.C.; Litinas, K.E.; Nicolaides, D.N.; Tsoleridis, K. Unexpected one-pot synthesis of new polycyclic coumarin[4,3-c]pyridine derivatives via tandem hetero-Diels-Alder and 1,3 dipolar cycloaddition reaction. Tetrahedron Lett. 2009, 50, 448-451. [CrossRef]

44. Nicolaides, D.N.; Fylaktakidou, K.C.; Litinas, K.E.; Hadjipavlou-Litina, D. Synthesis and Biological Evaluation of Several Coumarin-4-Carboxamidoxime and 3-(Coumarin-4-yl)-1,2,4-oxadiazole Derivatives. Eur. J. Med. Chem. 1998, 33, 715-724. [CrossRef]

45. Nicolaides, D.N.; Litinas, K.E.; Vrasidas, I.; Fylaktakidou, K.C. Thermal Transformation of Arylamidoximes in the Presence of Phosphorous Ylides. Unexpected Formation of 3-Aryl-5-Arylamino-1,2,4-Oxadiazoles. J. Heterocycl. Chem. 2004, 41, 499-503. [CrossRef]

46. Nicolaides, D.N.; Litinas, K.E.; Papamehael, T.; Grzeskowiak, H.; Gautam, D.R.; Fylaktakidou, K.C. An Easy Transformation of 2-Amino-2-(hydroxyimino)acetates to Carbamoylformamidoximes. Synthesis 2005, 407-410. [CrossRef]

47. Fylaktakidou, K.C.; Litinas, K.E.; Saragliadis, A.; Adamopoulos, S.G.; Nicolaides, D.N. Synthesis of oxadiazoloquinoxaline, oxathiadiazoloquinoxaline and oxadiazolobenzothiazine derivatives. J. Heterocycl. Chem. 2006, 43, 579-583. [CrossRef]

48. Ispicoudi, M.; Litinas, K.E.; Fylaktakidou, K.C. A convenient synthesis of 5-amino-substituted-1,2,4-oxadiale derivatives via reactions of amidoximes with carbodiimides. Heterocycles 2008, 75, 1321-1328.

49. Ispicoudi, M.; Amvrazis, M.; Kontogiorgis, C.; Koumbis, A.E.; Litinas, K.E.; Hadjipavlou-Litina, D.J.; Fylaktakidou, K.C. Convenient Synthesis and Biological Profile of 5-Amino-substituted 1,2,4-oxadiazole Derivatives. Eur. J. Med. Chem. 2010, 45, 5635-5645. [CrossRef] [PubMed]

50. Doulou, I.; Kontogiorgis, C.; Koumbis, A.E.; Evgenidou, E.; Hadjipavlou-Litina, D.; Fylaktakidou, K.C. Synthesis of stable aromatic and heteroaromatic sulfonyl-amidoximes and evaluation of their antioxidant and lipid peroxidation activity. Eur. J. Med. Chem. 2014, 80, 145-153. [CrossRef] [PubMed]

51. Nielsen, P.E.; Jeppesen, C.; Egholm, M.; Buchardt, O. Photochemical cleavage of DNA by nitrobenzamides linked to 9-Aminoacridine. Biochemistry 1988, 27, 6338-6343. [CrossRef] [PubMed] 
52. Nielsen, P.E.; Egholm, M.; Koch, T.; Christensen, J.B.; Buchardt, O. Photolytic cleavage of DNA by nitrobenzamido ligands linked to 9-aminoacridines gives DNA polymerase substrates in a wavelength-dependent reaction. Bioconjugate. Chem. 1991, 2, 57-66. [CrossRef]

53. Hurley, R.; Testa, A.C. Triplet-State yield of aromatic nitro compounds. J. Am. Chem. Soc. 1968, 90, 1949-1952. [CrossRef]

54. Saito, I.; Takayama, M. Photoactivatable DNA-Cleaving Amino Acids: Highly Sequence-Selective DNA Photocleavage by Novel L-Lysine Derivatives. J. Am. Chem. Soc. 1995, 117, 5590-5591. [CrossRef]

55. Wondrak, G.T.; Jacobson, M.K.; Jacobson, E.L. Endogenous UVA-photosensitizers: Mediators of skin photodamage and novel targets for skin photoprotection. Photochem. Photobiol. Sci. 2006, 5, 215-237. [CrossRef] [PubMed]

56. Lalevée, J.; Allonas, X.; Fouassier, J.P.; Tachi, H.; Izumitani, A.; Shirai, M.; Tsunooka, M. Investigation of the photochemical properties of an important class of photobase generators: The O-acyloximes. J. Photochem. Photobiol. A 2002, 151, 27-37. [CrossRef]

57. Pearson, R.C. Electronic Spectra and Chemical Reactivity. J. Am. Chem. Soc. 1988, 110, 2092-2097. [CrossRef]

58. Varras, P.C.; Zarkadis, A.K. Ground- and Triplet Excited-State Properties Correlation: A Computational CASSCF/CASPT2 Approach Based on the Photodissociation of Allylsilanes. J. Phys. Chem. A 2012, 116, 1425-1434. [CrossRef] [PubMed]

59. Budyka, M.F.; Zyubina, T.S.; Zarkadis, A.K. Correlating ground and excited state properties: A quantum chemical study of the photodissociation of the C-N bond in N-substituted anilines. J. Mol. Struct. (Theochem) 2002, 594, 113-125. [CrossRef]

60. Budyka, M.F.; Zyubina, T.S.; Zarkadis, A.K. Quantum chemical study of the Si-C bond photodissociation in benzylsilane derivatives: A specific 'excited-state' silicon effect. J. Mol. Struct. (Theochem) 2004, 668, 1-11. [CrossRef]

61. Marazzi, M.; Wibowo, M.; Gattuso, H.; Dumont, E.; Roca-Sanjuán, D.; Monari, A. Hydrogen abstraction by photoexcited benzophenone: Consequences for DNA photosensitization. Phys. Chem. Chem. Phys. 2016, 18, 7829-7836. [CrossRef] [PubMed]

62. Zeglis, B.M.; Pierre, V.C.; Barton, J.K. Metallo-Intercalators and metallo-insertors. Chem. Commun. 2007, 4565-4579. [CrossRef] [PubMed]

63. Pyle, A.M.; Rehmann, J.P.; Meshoyrer, R.; Kumar, C.V.; Turro, N.J.; Barton, J.K. Mixed-Ligand complexes of ruthenium(II): Factors governing binding to DNA. J. Am. Chem. Soc. 1989, 111, 3051-3058. [CrossRef]

64. Pratviel, G.; Bernadou, J.; Meunier, B. DNA and RNA cleavage by metal complexes. Adv. Inorg. Chem. 1998, 45, 251-262.

65. Wolfe, A.; Shimer, G.; Meehan, T. Polycyclic aromatic hydrocarbons physically intercalate into duplex regions of denatured DNA. Biochemistry 1987, 26, 6392-6396. [CrossRef] [PubMed]

66. Dimitrakopoulou, A.; Dendrinou-Samara, C.; Pantazaki, A.A.; Alexiou, M.; Nordlander, E.; Kessissoglou, D.P. Synthesis, structure and interactions with DNA of novel tetranuclear, $\left[\mathrm{Mn}_{4}(\mathrm{II} / \mathrm{II} / \mathrm{II} / \mathrm{IV})\right]$ mixed valence complexes. J. Inorg. Biochem. 2008, 102, 618-628. [CrossRef] [PubMed]

67. Garcia-Gimenez, J.L.; Gonzalez-Alvarez, M.; Liu-Gonzalez, M.; Macias, B.; Borras, J.; Alzuet, G. Toward the development of metal-based synthetic nucleases: DNA binding and oxidative DNA cleavage of a mixed copper(II) complex with $\mathrm{N}$-(9H-purin-6-yl)benzenesulfonamide and 1,10-phenantroline. Antitumor activity in human Caco-2 cells and Jurkat T lymphocytes. Evaluation of p53 and Bcl-2 proteins in the apoptotic mechanism. J. Inorg. Biochem. 2009, 103, 923-934. [PubMed]

68. Liu, J.; Zhang, H.; Chen, C.; Deng, H.; Lu, T.; Li, L. Interaction of macrocyclic copper(II) complexes with calf-thymus DNA: Effects of the side chains of the ligands on the DNA-binding behaviors. Dalton Trans. 2003, 114-119. [CrossRef]

69. Lakowicz, J.R. Principles of Fluorescence Spectroscopy, 3rd ed.; Plenum Press: New York, NY, USA, 2006.

70. Wilson, W.D.; Ratmeyer, L.; Zhao, M.; Strekowski, L.; Boykin, D. The search for structure-specific nucleic acid-interactive drugs: Effects of compound structure on RNA versus DNA interaction strength. Biochemistry 1993, 32, 4098-4104. [CrossRef] [PubMed]

71. Zhao, G.; Lin, H.; Zhu, S.; Sun, H.; Chen, Y. Dinuclear palladium(II) complexes containing two monofunctional $[\mathrm{Pd}(\mathrm{en}) \text { (pyridine)Cl}]^{+}$units bridged by Se or S. Synthesis, characterization, cytotoxicity and kinetic studies of DNA-binding. J. Inorg. Biochem. 1998, 70, 219-226. [PubMed] 
72. Heller, D.P.; Greenstock, C.L. Fluorescence lifetime analysis of DNA intercalated ethidium bromide and quenching by free dye. Biophys. Chem. 1994, 50, 305-312. [CrossRef]

73. Marmur, J. A procedure for the isolation of deoxyribonucleic acid from micro-organisms. J. Mol. Biol. 1961, 3, 208-218. [CrossRef]

74. Reichmann, M.F.; Rice, S.A.; Thomas, C.A.; Doty, P. A Further Examination of the Molecular Weight and Size of Desoxypentose Nucleic Acid. J. Am. Chem. Soc. 1954, 76, 3047-3053. [CrossRef]

75. Buyle, R. Sur les esters activés I. Aminolyse des dérivés de oximes et amidoximes. Helv. Chim. Acta 1964, 47, 2444-2448. [CrossRef]

76. Image J; version 1.50.I. Available online: http://rsb.info.nih.gov/ij/download.html (accessed on 30 June 2016).

77. Frisch, M.J.; Trucks, G.W.; Schlegel, H.B.; Scuseria, G.E.; Robb, M.A.; Cheeseman, J.R.; Scalmani, G.; Barone, V.; Mennucci, B.; et al. Gaussian 09; Revision B.01; Gaussian, Inc.: Wallingford, CT, USA, 2009.

Sample Availability: Samples of all compounds are available from the authors.

(C) 2016 by the authors; licensee MDPI, Basel, Switzerland. This article is an open access article distributed under the terms and conditions of the Creative Commons Attribution (CC-BY) license (http://creativecommons.org/licenses/by/4.0/). 